\title{
DISCLAIMER
}

This report was prepared as an account of work sponsored by an agency of the United States Government. Neither the United States Government nor any agency thereof, nor any of their employees, makes any warranty, express or implied, or assumes any legal liability or responsibility for the accuracy, completeness, or usefulness of any information, apparatus, product, or process disclosed, or represents that its use would not infringe privately owned rights. Reference herein to any specific commercial product, process, or service by trade name, trademark, manufacturer, or otherwise does not necessarily constitute or imply its endorsement, recommendation, or favoring by the United States Government or any agency thereof. The views and opinions of authors expressed herein do not necessarily state or reflect those of the United States Government or any agency thereof.

\section{National Institutes of Health: Mixed Waste Minimization and Treatment}

Published August 1995

National Low-Level Waste Management Program

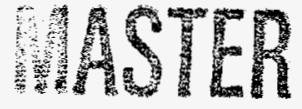

Prepared for Lockheed Idaho Technologies Company Under Subcontract No. C90-132744

and for the

U.S. Department of Energy

Assistant Secretary for Environmental Management

Contract DE-AC07-941D13223 


\section{DISCLAIMER}

Portions of this document may be illegible in electronic image products. Images are produced from the best available original document. 


\section{EXECUTIVE SUMMARY}

The Appalachian States Low-Level Radioactive Waste Commission requested the U.S. Department of Energy's National Low-Level Waste Management Program (NLLWMP) to assist the biomedical community in becoming more knowledgeable about its mixed waste streams, to help minimize the mixed waste streams generated by the biomedical community, and to identify applicable treatment technologies for these mixed waste streams. As the first step in the waste minimization process, liquid low-level radioactive mixed waste (LLMW) streams generated at the National Institutes of Health (NIH) were characterized and combined into similar process categories. The results of these evaluations were outlined in the National Institutes of Health: Mixed Waste Stream Analysis report (DOE/LLW-208).

This report identifies possible waste minimization and treatment approaches for the LLMW generated by the biomedical community identified in DOE/LLW-208. In development of the report, onsite meetings were conducted with NIH personnel responsible for generating each category of waste identified as lacking disposal options. Based on the meetings and general waste minimization guidelines, potential waste minimization options were identified. Conclusions from the study are as follows:

- Most of the reagents that are used in gel electrophoresis for gel fixing and washing (the largest portion of the difficult-to-manage LLMW at NIH) do not have substitutes acceptable to the research community at this time. However, there do appear to be substitution opportunities for using alternative gels that would require either a smaller volume of fixatives or would not require fixing or washing.

- Procedural changes appear to be a potential waste minimization approach for some research applications. In particular, chemiluminescent detection techniques could be used more widely as a substitute for techniques involving autoradiography. Also, additional expenditures for new equipment such as automated DNA sequencers could reduce waste volumes.

- There does not appear to be significant opportunities for LLMW volume reduction by segregation of radioactive and hazardous waste streams.

- The NIH radiation safety group appears to have done a good job of educating and informing the generators about the additional expense and effort required to manage mixed waste.

- Recycling opportunities are limited by both the precautions required for radioactive materials and by the lack of a simple, quick, and effective means of treating the waste reagents prior to their reuse.

- The waste produced by gel electrophoresis and filter washing techniques appears to be surprisingly uniform in character and composition, regardless of the specific research application. Such uniformity makes treatment options a potentially effective means of reducing LLMW volumes requiring disposal.

- An opportunity may exist for LLMW minimization through improved waste classification. Experience to date has shown that generators may be overestimating solvent concentrations in the waste resulting in misclassification of the waste as listed hazardous waste. Treatment residues of such listed waste must continue to be managed as hazardous waste, thereby significantly limiting disposal options. 



\section{CONTENTS}

EXECUTIVE SUMMARY $\ldots \ldots \ldots \ldots \ldots \ldots \ldots \ldots \ldots \ldots \ldots \ldots \ldots \ldots$ iii

FIGURES $\ldots \ldots \ldots \ldots \ldots \ldots \ldots \ldots \ldots \ldots \ldots \ldots \ldots \ldots \ldots \ldots \ldots$ vii

TABLES $\ldots \ldots \ldots \ldots \ldots \ldots \ldots \ldots \ldots \ldots \ldots \ldots \ldots \ldots \ldots \ldots \ldots \ldots \ldots \ldots$

ACRONYMS AND ABBREVIATIONS $\ldots \ldots \ldots \ldots \ldots \ldots \ldots \ldots \ldots \ldots \ldots$ ix

1.0 INTRODUCTION $\ldots \ldots \ldots \ldots \ldots \ldots \ldots \ldots \ldots \ldots \ldots \ldots \ldots \ldots \ldots \ldots$

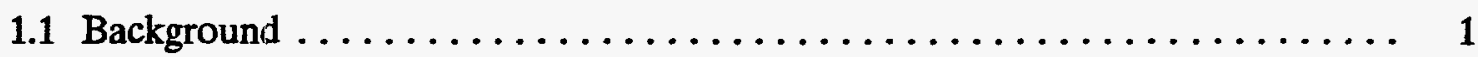

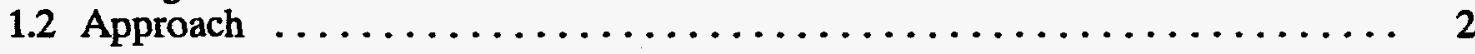

2.0 PROCESS INFORMATION $\ldots \ldots \ldots \ldots \ldots \ldots \ldots \ldots \ldots \ldots \ldots \ldots \ldots \ldots$

2.1 Background Information on Waste Generating Processes ........... 3

2.1.1 Electrophoresis Gel Fixing/Washing for Protein, DNA Separation ... 3

2.1.2 Electrophoresis Gel Fixing/Washing for DNA Sequencing ....... 5

2.1.3 HPLC Scintillation Counting $\ldots \ldots \ldots \ldots \ldots \ldots \ldots \ldots \ldots \ldots \ldots \ldots$

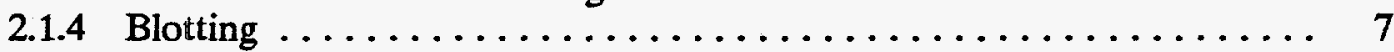

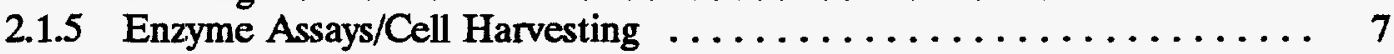

2.1.6 Staining/Destaining $\ldots \ldots \ldots \ldots \ldots \ldots \ldots \ldots \ldots \ldots \ldots \ldots \ldots \ldots$

2.2 Background Information on Waste Minimization Approaches $\ldots \ldots \ldots \ldots$

2.2.1 Substitution of Reagents $\ldots \ldots \ldots \ldots \ldots \ldots \ldots \ldots \ldots \ldots \ldots$

2.2.2 Changes in Techniques and Procedures $\ldots \ldots \ldots \ldots \ldots \ldots \ldots \ldots$

2.2.3 Improved Waste Segregation $\ldots \ldots \ldots \ldots \ldots \ldots \ldots \ldots \ldots \ldots \ldots$

2.2 .4 Recycling ........................... 11

2.2.5 Improved Waste Classification $\ldots \ldots \ldots \ldots \ldots \ldots \ldots \ldots \ldots \ldots \ldots$

3.0 LLMW GENERATOR INTERVIEWS $\ldots \ldots \ldots \ldots \ldots \ldots \ldots \ldots \ldots$

4.0 ASSESSMENT OF WASTE MINIMIZATION OPTIONS . . . . . . . . . . 19

4.1 Electrophoresis Gel Fixing/Washing Options ............... 19

4.1.1 Changes in Procedures . . . . . . . . . . . . . . . . 19

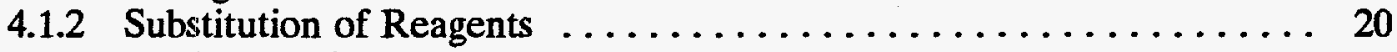

4.1 .3 Equipment Changes ........................ 21

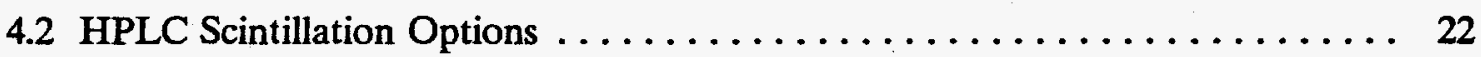

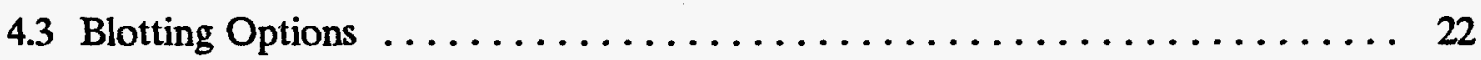

4.3.1 Use of Nonradiolabeled Molecules ................... 22

4.3.2 Reagent Substitution ........................ 23

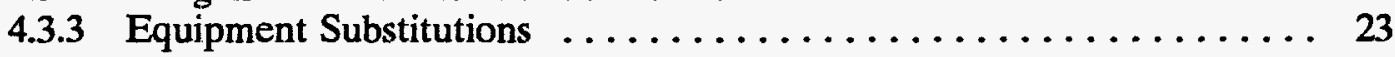


4.4 Options for Enzyme Assays/Cell Harvesting $\ldots \ldots \ldots \ldots \ldots \ldots \ldots \ldots \ldots$

4.4.1 Reagent Substitutions $\ldots \ldots \ldots \ldots \ldots \ldots \ldots \ldots \ldots \ldots \ldots \ldots \ldots$

4.4.2 Equipment Modifications .................... 24

4.5 Options for Staining/Destaining $\ldots \ldots \ldots \ldots \ldots \ldots \ldots \ldots \ldots \ldots \ldots \ldots \ldots$

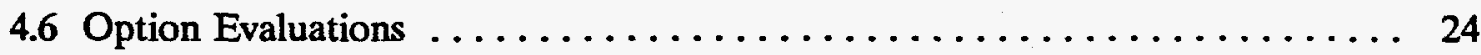

5.0 WASTE TREATMENT OPTIONS $\ldots \ldots \ldots \ldots \ldots \ldots \ldots \ldots \ldots \ldots \ldots$

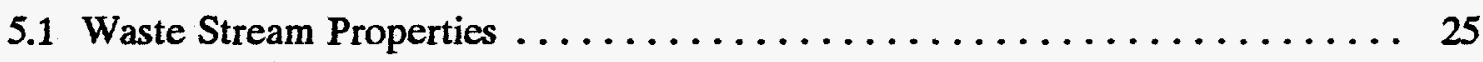

5.2 Treatment Technologies/Processes $\ldots \ldots \ldots \ldots \ldots \ldots \ldots \ldots \ldots \ldots \ldots$

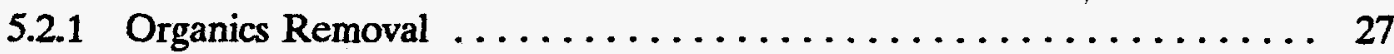

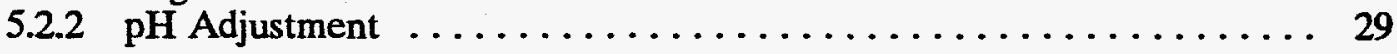

5.3 Proposed Treatment Process $\ldots \ldots \ldots \ldots \ldots \ldots \ldots \ldots \ldots \ldots \ldots$

6.0 CONCLUSIONS AND RECOMMENDATIONS $\ldots \ldots \ldots \ldots \ldots \ldots \ldots \ldots$

7.0 REFERENCES $\ldots \ldots \ldots \ldots \ldots \ldots \ldots \ldots \ldots \ldots \ldots \ldots \ldots \ldots \ldots \ldots \ldots \ldots$

APPENDIX A - SUMMARY OF GENERATOR INTERVIEWS $\ldots \ldots \ldots \ldots \ldots$ A-1 


\section{FIGURES}

5-1 Recommended process for organic LLMW treatment

\section{TABLES}

3-1 Pros and cons of fixing and washing electrophoresis gels $\ldots \ldots \ldots \ldots \ldots \ldots$

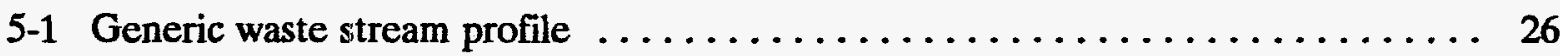

6-1 Summary of feasibility of waste minimization options $\ldots \ldots \ldots \ldots \ldots$

Mention of a commercial product or firm does not constitute endorsement of that product or firm by the U.S. Department of Energy, the U.S. Department of Health and Human Services, or any of their contracting firms. 


\title{
ACRONYMS AND ABBREVIATIONS
}

\author{
AEA Atomic Energy Act \\ ALARA - as low as reasonably achievable \\ CFR Code of Federal Regulations \\ DNA deoxyribonucleic acid \\ DSSI Diversified Scientific Services, Incorporated \\ ELISA enzyme linked immuno sorbent assay \\ EPA U.S. Environmental Protection Agency \\ GAC granulated activated carbon \\ HIV human immunodeficiency virus \\ HPLC high-performance liquid chromatography \\ HRP horseradish peroxidase \\ HSSDS Hazardous Solvent Substitution Data System \\ LLMW low-level radioactive mixed waste \\ LLW low-level radioactive waste \\ LSC liquid scintillation counting \\ ml milliliter \\ $\mathrm{NaOH} \quad$ sodium hydroxide \\ NIH National Institutes of Health \\ NLLWMP National Low-Level Waste Management Program \\ nm nanometer \\ ppm parts per million \\ PPO Solvent manufactured by Eastman Chemical with formula 2,5 diphenyloxazole \\ PVDR polyvinylidene difluoride \\ RCRA Resource Conservation and Recovery Act \\ RNA ribonucleic acid \\ RT \\ SDS \\ SEG \\ SFC \\ TCA \\ reverse transcriptase \\ sodium dodecyl sulphate \\ Scientific Ecology Group, Incorporated \\ TIGR The Institute for Genomic Research \\ UV \\ ultraviolet
}




\section{NATIONAL INSTITUTES OF HEALTH: MIXED WASTE MINIMIZATION AND TREATMENT}

\subsection{INTRODUCTION}

\subsection{Background}

Currently, management of mixed waste $\mathrm{e}^{\mathrm{a}}$ is a challenge for states, regional compacts, and biomedical mixed waste generators because offsite treatment and disposal facilities are limited. The U.S. Department of Energy's National Low-Level Waste Management Program (NLLWMP) has been requested by the Appalachian States Low-Level Radioactive Waste Commission to assist the biomedical community to become better acquainted with its mixed waste steams, to help minimize the mixed waste streams generated by the biomedical community, and to identify applicable treatment technologies for those particular mixed waste streams. As the first step in the waste minimization process, liquid low-level radioactive mixed waste streams (LLMW) generated at the National Institutes of Health (NIH) were characterized and combined into similar process categories. The results of these evaluations were outlined in the National Institutes of Health: Mixed Waste Stream Analysis report (DOE/LLW-208).

That analysis compiled information on each container of LLMW at the NIH and consolidated mixed waste stream data into process groups that appeared to be derived from similar activities. Because liquid scintillation wastes were being actively and adequately managed, they were not included in the scope of that study. The container inventory information is maintained by the NIH in the form of a computerized waste stream database. The processes were grouped into 32 categories ( 31 similar processes and 1 unknown category). The groupings were based on a comparison of the descriptions of the waste generating processes provided for each container of mixed waste in the database. The groupings were used to identify the major processes and to develop characterizations of the waste produced.

The objective of this report is to identify possible minimization and treatment approaches for those ILLMW generated by the biomedical community that were identified in DOE/LLW-208. This scope of work includes further characterization of the generating

a. Mixed waste is defined in the Federal Facilities Compliance Act amendments to the Resource Conservation and Recovery Act (42 USC 6901 et seq.) as a waste that contains both hazardous waste and source, special nuclear, or byproduct material subject to the Atomic Energy Act of 1954, as amended. 
processes for LLMW previously identified as being difficult to dispose of. Specifically, ways to prevent or minimize the generation of these more difficult-to-manage mixed wastes are identified, keeping in mind that biomedical research will need to continue. Options for treatment, minimization, alternative processes, and chemical substitutions are also evaluated.

\subsection{Approach}

As a first step, onsite meetings were conducted with NIH personnel responsible for generating each of the categories of waste identified as lacking disposal options. The onsite discussions also confirmed the accuracy of characterization information contained in the NIH waste stream database. The meetings focused on in-depth analyses of the specific processes generating the waste and identifying potential opportunities for waste minimization.

Based on the meetings and general waste minimization guidelines, potential waste minimization options were identified. The range of potential options included:

- Material substitution of nonhazardous or nonradioactive process inputs

- $\quad$ Procedural changes concerning material handling

- $\quad$ Process modifications

- Segregation of radioactive and hazardous waste streams

- Recycle/reuse of a mixed waste stream

- Waste treatment to reduce toxicity or remove hazardous constituents

- Volume reduction

- $\quad$ Stabilization.

Potential waste minimization options identified were then evaluated relative to their applicability to the NIH waste streams.

The following sections outline the results of the NIH mixed waste stream analyses. Section 2.0 discusses general biomedical mixed waste generating processes and waste minimization approaches. Section 3.0 provides an overview and summary of the 20 interviews with NIH LLMW generators. Section 4.0 identifies various waste minimization options for the waste streams generated at the NIH. Section 5.0 discusses general waste treatment options for previously generated NIH LLMW. Section 6.0 summarizes the overall results of the evaluations and provides recommendations. 


\subsection{PROCESS INFORMATION}

A total of 20 interviews were conducted with NIH researchers in organizations that represented a broad cross-section of NIH activities. Based on those interviews, Section 2.1 provides background information on the main NIH processes that generate LLMW and Section 2.2 summarizes general waste minimization approaches for such LLMW.

\subsection{Background Information on Waste Generating Processes}

Most of the waste produced by the LLMW generators who were interviewed were produced by six analytical procedures and techniques. Each of these is described in general in the following sections.

\subsubsection{Electrophoresis Gel Fixing/Washing for Protein, DNA Separation}

An analysis of the NIH mixed waste streams found that the largest portion of the LLMW, which did not have disposal options at the time of the analysis, was derived from electrophoresis gel fixing and/or washing (DOE/LLW-208). Gel electrophoresis is a valuable tool for making separations of protein or deoxyribonucleic acid/ribonucleic acid (DNA/RNA) fragments. This technique is used to separate, identify, and purify fragments and is often used to determine the sequence of bases in nucleic acids. As discussed below, radiolabeling of the protein or DNA fragments, coupled with fixing and washing of the gels, results in generation of the LLMW.

The amount of waste generated depends on the type of gel used and the type and amount of reagent used in processing the gel. All of the gels are constructed of polyacrylamide or agarose. These chemicals act as porous media that behave like sieves by retarding or obstructing the movement of the protein or DNA/RNA molecules while allowing smaller molecules to migrate freely. The size of the gel pore determines the extent of the molecular sieving. The mobility of molecules through gels is sensitive to $\mathrm{pH}$, which must be controlled. To control $\mathrm{pH}$, the molecules being evaluated are dissolved in an aqueous buffer system that maintains the $\mathrm{pH}$ required for the separation. In some systems, two buffers are used, a "running" buffer for the sample and a gel buffer. The molecules migrate through the gel media when subjected to an electric field. The mobility of the molecules through the electric field is determined by the strength of the field and the charge, size, and shape of the molecule.

Generally, different types of gels are used for protein separation and for DNA/RNA separation. Large pore gels such as those made with agarose are used to separate macromolecules such as DNA/RNA and large proteins. The pore size of polyacrylamide gels is determined by the concentration of acrylamide in the gel. Acrylamide gels are characterized by the concentrations of acrylamide monomer and bisacrylamide crosslinking 
agent that are used to produce the gel. It is important to use an appropriate gel for the separation being studied. The size and nature of the molecule and the nature of the sample are all factors in selecting the correct gel.

When polyacrylamide gels are used to separate proteins, a dissociating or nondissociating buffer system can be used. In a dissociating system, the protein is first dissociated or broken up into polypeptide subunits by using sodium dodecyl sulphate (SDS) and by heating the protein sample. These subunits are then solubilized and can be separated in gels. This type of system is referred to as SDS PAGE. Nondissociating buffer systems can also be used. These systems are designed to fractionate a protein mixture such that subunit interaction, protein conformation, and biological activity are preserved.

For protein separation, the protein can be removed for further use or autoradiographic images can be made of the radiolabeled proteins on the gel. In both of these cases, the gel is often fixed with reagents such as trichloroacetic acid (TCA), or methanol/acetic acid to precipitate the protein and remove such contaminants as urea.

For gel electrophoresis of DNA fragments, agarose is typically used for analyzing larger molecules. However, due to its large pore size, agarose does not provide optimal resolution for smaller molecules. Polyacrylamide gels can be used for smaller DNA fragments up to about 2,000 base pairs in length. Another advantage of polyacrylamide gels is that the DNA recovered is relatively pure and can be used for additional applications without extensive purification. Double-stranded DNA can be separated using nondenaturing polyacrylamide gels. Most of these DNA strands will migrate through nondenaturing polyacrylamide with a mobility inversely proportional to the number of base pairs. However, this mobility is affected by the actual base composition and sequence of the DNA strand such that DNA fragments of identical size can migrate at significantly different rates. Therefore, it is not always possible to determine the DNA molecular weight in these nondenaturing systems.

A double strand of DNA can be denatured, or split into single strands, by using urea, formamide, or sodium hydroxide $(\mathrm{NaOH})$ that suppresses the base pairing in the double strands. Typically, the denaturing agent is incorporated in the gel by polymerizing the gel in its presence. Denatured, single-stranded DNA will migrate through denaturing gels at a rate that is nearly independent of the base composition and sequence of the DNA that allows a more accurate determination of the molecular weight of the DNA strand. This is less true for smaller single-stranded DNA fragments, however.

After the gel electrophoresis step is complete, the separated DNA can be removed from the gel for further work, or photographs of the separated bands of DNA on the gel surface can be made. There are two methods of photographing the gel. The first method does not use radioactive materials. In this method, the DNA is stained with a powerful 
fluorescent dye such as ethidium bromide. The dye bound to DNA displays an increased fluorescent yield compared to dye in free solution when exposed to ultraviolet (UV) radiation. The energy is re-emitted at 590 nanometers $(\mathrm{nm})$ in the red-orange region of the visible spectrum. A photograph is made of the stained DNA by directing a UV source at the gel and photographing the resultant phosphorescence. This dye can be used to detect both single- and double-stranded DNA. However, the affinity of this dye for single-stranded nucleic acid is relatively low and the fluorescent yield is poor. The second method of DNA detection requires that the DNA be labeled with a radionuclide such as ${ }^{32} \mathrm{P}$ or ${ }^{35} \mathrm{~S}$. After separation, the gel is placed in contact with photographic film and the radiation emitted from the radionuclides will expose a characteristic pattern on the film. This second method is termed autoradiography. Some researchers use both autoradiography and fluorescent techniques.

The volume of buffer used for gel electrophoresis is typically quite small relative to the volume of fixing and washing solutions that are used. The buffer, therefore, is not a significant contributor to the volume of mixed waste produced with radiolabeled DNA. If DNA is labeled with a radionuclide such as ${ }^{32} \mathrm{P}$ and an agarose gel is being used, it is typically soaked in a $7 \%$ solution of TCA following the electrophoresis. This solution becomes a mixed waste after coming into contact with the radiolabeled DNA. Following this fixing step, the gel is dried for several hours. When polyacrylamide gels are used with DNA containing radionuclides, they are typically immersed in a fixative solution of acetic acid followed by drying. The drying step is required for DNA labeled with ${ }^{35} \mathrm{~S}$ (a weak Beta emitter) or very small quantities of ${ }^{32} \mathrm{P}$ to reduce the exposure time required for a satisfactory autoradiographic image.

\subsubsection{Electrophoresis Gel Fixing/Washing for DNA Sequencing}

Perhaps the most widely used application for gel electrophoresis is to determine the sequence of the bases comprising a segment of unknown DNA. Most of the LLMW produced during DNA sequencing activities is a result of fixing the gels prior to autoradiography. The gels are often fixed by soaking them in a bath of $10 \%$ methanol and $10 \%$ acetic acid in water. The fixing removes the urea that might otherwise prevent the gel from drying out and might cause it to stick to the autoradiographic film.

Two common, but differing, methods are used for DNA sequencing. In the Sanger method, a single-stranded template DNA fragment is used to synthesize new DNA with DNA polymerase until a DNA chain terminates. By using chain termination agents that are specific for each of the four bases in four sets of reactions, a population of oligonucleotides are produced for each reaction that terminate at four positions in the template DNA strand. These four reaction mixtures are then loaded into adjacent lanes of a DNA sequencing gel and the order of the bases in the DNA can be read directly from an autoradiographic image of the gel. To produce this image, the DNA is usually labeled with ${ }^{32} \mathrm{P}$ or ${ }^{35} \mathrm{~S}$. The ${ }^{32} \mathrm{P}$ is 
less commonly used because the high-energy beta particles that it emits form larger and more diffuse bands on the autoradiograph due to scattering and also cause radiolysis of the DNA in the sample if it is stored for more than 1 to 2 days. The beta particles emitted by the ${ }^{35} \mathrm{~S}$ produce a higher resolution autoradiograph image. From the standpoint of waste minimization, ${ }^{33} \mathrm{P}$ can be used as a substitute for ${ }^{35} \mathrm{~S}$. It is reported to provide better resolution and sensitivity than ${ }^{32} \mathrm{P}$ and shorter autoradiographic exposure times than ${ }^{35} \mathrm{~S}$ but is more costly than either of these radionuclides (Party and Gershey, 1995).

In the Maxam-Gilbert sequencing method, a DNA fragment, radiolabeled at one end, is chemically separated in five separate chemical reactions, each of which is specific for a particular base or type of base. This produces five populations of radiolabeled molecules that extend from the common radiolabeled end-point to the site of the chemical separation. Each population consists of a mixture of molecules whose lengths are determined by the locations of a particular base along the length of the original DNA fragment. The populations are then separated by gel electrophoresis and the end-labeled molecules are detected by autoradiography. By comparing the separations from each of the five populations, the sequence can be determined.

\subsubsection{HPLC Scintillation Counting}

Another large volume waste identified in the NIH database is the high-performance liquid chromatography (HPLC) scintillation counting. LLMW HPLC scintillation counting fluid wastes are generated when two powerful analytical techniques, HPLC and liquid scintillation counting are used. HPLC is a type of liquid chromatography in which liquid samples to be analyzed are injected directly into a column through which a solvent is pumped at high pressures. The various types of molecules contained within the sample are separated as they pass through the column, depending on the specificity of the column, and exit the column at different times that are characteristic of the different molecular species.

Liquid scintillation counting (LSC) is a technique to detect beta radiation (also alpha radiation, positrons, and weak $\mathrm{x}$-rays) emitted by radioactively labeled chemicals. In this technique, ionizing radiation passing through a dilute solution of an organic substance causes ionization and excitation of some of the solvent molecules through promotion of pi-orbital electrons to higher energy states. If a suitable solute is present in the solution, these electrons will transfer their excitation energy to the solute molecules, which then emit multiple light flashes (scintillations) through solute fluorescence as they return to lower energy states. The scintillations are then recorded with photomultiplier tubes. In biomedical research, the technique is widely used to measure ${ }^{14} \mathrm{C}$ and ${ }^{3} \mathrm{H}$, as well as other nuclides. When the scintillation counting technique is applied to solvents from a HPLC column, it provides a powerful technique for quantitatively detecting the presence of biochemical species of interest. 
The key points with respect to waste generation are that the use of a suitable solvent with pi-orbital electrons is required together with a solute appropriate for the solvent being used. The solvent used with LSC is typically referred to as a "cocktail" and is usually a proprietary vendor-supplied mixture. During the laboratory process, materials such as acetonitrile and methanol may be added potentially resulting in the generation of an F-listed hazardous waste. The automatic HPLC equipment can operate 24 hours per day generating approximately 10 milliliters (ml) of LLMW per minute of operation.

LSC is also used without a HPLC column. In this case, the LSC cocktail is usually enclosed within a small vial that is used and then discarded. The discarded vials can usually be disposed of by shipping them to an off-site commercial facility in Florida for processing and fuel recovery. This waste stream is, therefore, not a part of this study.

\subsubsection{Blotting}

Protein residues, which are separated using gel electrophoresis techniques, can be transferred from the sequencing gel to a membrane in a process called "blotting." Membranes are constructed of media such as nitrocellulose, Nylon ${ }^{\mathrm{m}}$, or polyvinylidene difluoride (PVDF). This electrophoretic transfer of proteins or "western blotting" consists of the transfer of proteins from the gel onto the membrane surface. Typically, after electrophoresis, the protein molecule is trapped within the gel matrix and is relatively inaccessible. However, if it is transferred to a membrane surface, it becomes easily accessible to many detection and analysis techniques. In the blotting process, a gel is layered next to the membrane. After the protein is transferred to the filter paper, it is washed using reagents such as methanol or ethanol to improve retention on the membrane and to remove impurities prior to further analysis. The membrane or blot washings can produce a LLMW depending on the reagents used.

\subsubsection{Enzyme Assays/Cell Harvesting}

Frequently, the presence of a particular protein in a cell culture must be determined. The protein typically has been previously radiolabeled with a radionuclide such as ${ }^{3} \mathrm{H}$ in a cell culture. Then, the cultured cells will be lysed with TCA and the resultant protein fragments will be aspirated and filtered with a cell harvester. The fragments can be washed with methanol to precipitate them and a radioassay via scintillation counting can be made of the protein fragments to determine if the radiolabeled protein is present. LLMW is generated from both the washes and liquid scintillation counting.

Assays for reverse transcriptase (RT) activity in specific viruses, such as human immunodeficiency virus (HIV), are also frequently performed on cell cultures. In this procedure, thymidine labeled with ${ }^{3} \mathrm{H}$ is incorporated into acid precipitable material. Then, the non-incorporated thymidine is removed and the cell culture is rinsed with $10 \%$ TCA 
followed by rinsing with $100 \%$ methanol. The remaining material is filtered in a cell harvester and the precipitated, labeled material is radioassayed. The rinses and washes in this procedure produce a LLMW, as well as the waste generated from LSC.

In addition to being a LLMW, many such wastes are also potentially infectious. The potential presence of infectious agents or components that are also regulated as medical waste often precludes the few available treatment options. Onsite inactivation of biohazards by autoclaving or chemical disinfection may alter the waste, increase volumes, or introduce new contaminants. The treatment and management of infectious mixed waste were not within the scope of this report.

\subsubsection{Staining/Destaining}

Silver staining is a method of creating light and dark bands from proteins or DNA in electrophoresis gels that can be directly photographed. Silver in an ionic form is added to the gel and reduced to metallic silver. Protein bands appear in the gel due to differences in the oxidation/reduction potentials between sites in gels occupied by protein and adjacent sites not occupied by protein. If protein-occupied sites have the higher reducing potential, then positive images are formed. If sites unoccupied by protein have the higher reducing potential, then negative images are formed.

Prior to the staining procedure, the gel is first fixed in a solution of ethanol, glacial acetic acid, and water, followed by an additional washing with $30 \%$ ethanol. LLMW can be produced if the silver staining is being used in conjunction with radiolabeled proteins or DNA. The silver reduction reaction is typically quenched by washing the gel in $1 \%$ acetic acid for several minutes.

A second method of staining is the use of Coomassie Blue stain for proteins separated on SDS polyacrylamide gels. With this stain, the gels are first fixed with methanol and glacial acetic acid followed by Coomassie Brilliant Blue R250. LLMW can also be produced using this stain if radiolabeled proteins are being stained. Generally, silver staining offers much more sensitivity than Coomassie Blue.

Following the staining with Coomassie Blue, the gel is typically destained by soaking it in a $30 \%$ methanol/10\% acetic acid solution. This process will again generate a LLMW if radioactivity is present.

\subsection{Background Information on Waste Minimization Approaches}

Waste minimization concepts that may be appropriate for the waste streams outlined above are described in the U.S. Environmental Protection Agency's (EPA's) Waste Minimization Opportunity Assessment Manual (EPA/625/7-88/003). In the manual, waste 
minimization is defined as "source reduction to reduce or eliminate waste generation, followed by recycling or reuse where wastes are unavoidable, and finally, minimization of the volume, toxicity, and mobility of waste generated through treatment and stabilization." Thus, a range of methods and technologies is available that can be used to implement an effective waste minimization program. The following section discusses general waste minimization options determined to be appropriate for most biomedical operations. Specific application of these techniques to the NIH mixed waste streams is discussed in Section 4.0.

\subsubsection{Substitution of Reagents}

To reduce the volume and/or the chemical or radiological hazard of the waste produced, nonhazardous short half-life radioactive or nonradioactive reagents can be substituted into the process. Three main factors determine the applicability of substitution: an evaluation to identify the reaction inputs that produce the hazardous or radioactive component of each mixed waste stream; the purpose of introducing the input that produced the mixed waste into the component; and identification of a substitute that will acceptably perform the intended function of the original input while at the same time reduce the volume or hazard of the waste stream.

The primary radionuclides that biomedical facilities use in their research are: ${ }^{125} \mathrm{I}$ as a tracer for labeled proteins in research; ${ }^{3} \mathrm{H}$ (tritium) and ${ }^{14} \mathrm{C}$ in certain analytical techniques; ${ }^{35} \mathrm{~S}$ and ${ }^{32} \mathrm{P}$ for labeling proteins and DNA with autoradiography; and ${ }^{3} \mathrm{H},{ }^{14} \mathrm{C},{ }^{32} \mathrm{P},{ }^{35} \mathrm{~S}$, and ${ }^{125}$ I for sample counting with liquid scintillation techniques. ${ }^{33} \mathrm{P},{ }^{51} \mathrm{Cr}$, and others are also used.

Material substitution options for such activities include substituting short-lived radionuclides such as ${ }^{131} \mathrm{I}$ for ${ }^{125} \mathrm{I}$, and ${ }^{32} \mathrm{P}$ in place of longer-lived radionuclides such as ${ }^{35} \mathrm{~S}$. Also, ${ }^{33} \mathrm{P}$ can be substituted for ${ }^{35} \mathrm{~S}$ or ${ }^{32} \mathrm{P} .{ }^{33} \mathrm{P}$ has a shorter half-life ( 25 days) than ${ }^{35} \mathrm{~S}$ (88 days) but a longer half-life than ${ }^{32} \mathrm{P}$ (14 days). Consequently, ${ }^{32} \mathrm{P}$ is preferred over ${ }^{33} \mathrm{P}$ from a waste minimization perspective. However, as noted in Section $2.1 .2,{ }^{33} \mathrm{P}$ provides better resolution and sensitivity than ${ }^{32} \mathrm{P}$ and comparable results to ${ }^{35} \mathrm{~S}$. If substitution of shortlived radionuclides is to be used in conjunction with storage for decay, the radioactive materials license of the facility must specifically allow such a waste management strategy. Release limits are specifically included in the facility license and are usually set so that no residual activity can be detected by normal means of measurement. Also, the potential for increased radiation exposure of laboratory personnel arising from use of substitute radionuclides must be considered before substitutions are made. Waste minimization strategies should not conflict with the principles of maintaining radiation exposures of personnel to levels that are as low as reasonably achievable (ALARA). Following decay and release, the waste can be managed without regard to its radioactivity and can be managed as hazardous waste only. 
Use and generation of lower concentrations of radioactive liquid waste can also increase the management options that are available. One regulatory standard in $10 \mathrm{CFR}$ $\$ 20.2003$ allows disposal by release into a sanitary sewerage system provided the material is readily soluble in water or is readily dispersible biological material, and the concentrations are at or below specified levels. Another regulatory provision, 10 CFR $\$ 20.2005$, allows disposal of LSC medium or animal carcasses without regards to their radioactivity provided the concentration of ${ }^{3} \mathrm{H}$ or ${ }^{14} \mathrm{C}$ is $\mathbf{0 . 0 5}$ microcurie or less per gram under certain conditions. Other techniques include the use of higher flash point solvents to avoid generation of Resource Conservation and Recovery Act (RCRA) hazardous wastes, and the elimination of organic solvents during preparation and analytical processes by using supercritical fluid chromatography (SFC). Highly automating the process and providing reproducible characteristics of a SFC can reduce the need for organic solvents.

\subsubsection{Changes in Techniques and Procedures}

Changing laboratory techniques and procedures, and providing more detailed guidance concerning material handling, can result in significantly reduced wastes for a minimal cost. For instance, a mixed waste is often generated as a result of the way a chemical or material is used, handled, or stored. Operational practices and procedures can be examined to determine if changes can be made.

An example of a change in technique is researchers who use smaller volumes of reagents to accomplish a particular objective. Illustrative of this approach are those researchers who were found to fix DNA sequencing gels with a much smaller volume of reagents, thereby reducing LLMW volume, than other researchers who were performing the same procedure.

An additional example of a change in practice would be inventory control. Laboratories can consider purchasing based on the amount of material needed rather than purchasing based on price per volume. If a facility determines that only one liter of a solvent-based reagent is used before the shelf life expires, it can request one-liter containers of this material in the future. This approach can reduce LLMW volume if the facility previously was purchasing larger containers that provide more material than was required.

Specific process modifications can also reduce the volume or degree of hazard (either chemical or radiological) of the waste stream. Factors determining if a process modification is applicable include the ability to identify the step in the process that actually produces the mixed waste; the purpose of the step that produces the mixed waste; and the availability of modifications that can be made to the process or alternative process that will acceptably perform the objective of the original process step, while at the same time reducing the volume or hazard of the waste stream. 
An example of a process modification could be the use of small-bore tubing on HPLC. The tubing would reduce the amounts of solvents and buffers required to perform analytical procedures.

The waste minimization practices that the NIH employs for lead are also an example of procedural change. The procurement of lead containers is discouraged, as is the use. Contamination of lead pigs is prevented by using liners of various types. If the lead becomes contaminated, it is decontaminated, allowing it to be recycled or reclaimed.

\subsubsection{Improved Waste Segregation}

This mixed waste minimization technique can be accomplished by simply preventing the hazardous and radiological components of the waste from being mixed. To implement this approach, the current laboratory process must be examined to determine if there is any mixing of hazardous and radioactive waste streams. If mixing of streams is indicated, the next step is to determine if the streams can be separated without unacceptable effects on the process.

Often, several wastes from many processes are combined, and segregation options can be applied to the operation. The mixed waste volume can be reduced if the combination of wastes is controlled at the source, and mixed waste fractions are segregated from other waste forms. A major contribution to mixed waste volume minimization includes separating aqueous components from the organic components. Examples of successfully eliminating contact between hazardous and radioactive waste streams include the use of segregated areas for hazardous and radioactive waste to avoid cross-contamination, and sorting hazardous and radioactive wastes into designated bins at the point where they are first generated, such as low-level radioactive waste (LLW), sanitary waste, RCRA hazardous waste, and mixed waste.

One example of waste segregation at NIH is a simple valve apparatus that can be added to washings of cell cultures. The aqueous washings are valved into a separate collection flask from the organic washings.

\subsubsection{Recycling}

Many mixed waste streams generated in the laboratory contain recoverable components that can be recycled and reused. An example of reuse would be to recover methanol from gel fixing/washing wastes. However, the recovery, decontamination, and purification of the methanol presents many difficulties that make its reuse impractical. These difficulties include providing and operating the equipment, final product purity, processing cost, and licensing and permitting requirements. Because of these difficulties, there are no outside facilities available for recycling radioactively contaminated solvents for

reuse as a solvent. One other recycling option is the reuse of waste materials as alternative 
fuels. Diversified Scientific Services Incorporated (DSSI), a subsidiary of Chem-Nuclear Systems Inc., operates a facility in Kingston, Tennessee, which will accept certain types of solvent mixed wastes for use as a fuel in power-generating combustion equipment.

Another more feasible approach to recycling is one in which specific solvent mixtures with relatively low levels of contamination are reused by the generator before being discarded. For example, some researchers may use a solvent mixture to fix more than one electrophoresis gel before discarding the solvent as a waste. Also, lead shielding "pigs" used for radionuclide shipping containers can be recycled in several ways. Uncontaminated pigs can be reused in laboratories or shipped to reclamation facilities. Contaminated pigs are decontaminated and shipped to reclamation facilities, although the decontamination procedure can also produce a LLMW. No lead shielding materials are disposed of as a LLMW by NIH.

\subsubsection{Improved Waste Classification}

Individual researchers can overestimate the concentrations of hazardous constituents in their waste. Regulatory characterizations are performed at the NIH waste processing facility by waste management personnel based on data provided by the researchers. Overestimation by the laboratories of the concentrations of solvents may result in mischaracterization of the waste as a listed waste. To be classified as mixed waste, the laboratory waste material must contain both radionuclides subject to the Atomic Energy Act (AEA) regulation and a RCRA waste (see mixed waste definition in Section 1.1). Mixed wastes that do not contain both of these components may be disposed of as a radioactive, hazardous, or solid waste. ${ }^{b}$

EPA listed approximately 130 industrial waste streams as hazardous waste (the $F$ - and $\mathrm{K}$-listed wastes). These wastes were listed because they exhibit one or more of the characteristics of hazardous wastes, or they contain specific components known to be toxic or otherwise hazardous at levels of regulatory concern.

The definition of F-listed wastes includes (1) spent halogenated and non-halogenated solvents, and (2) mixtures containing, before or after use, a total of $10 \%$ or more by volume of these solvents. Experience of NIH personnel responsible for waste disposal indicates that laboratories, by overestimating these solvent concentrations, may mischaracterize their wastes as F-listed solvents rather than ignitable characteristic wastes. Such mischaracterization can result in greater difficulty for disposal of treatment residues of listed wastes since they remain as hazardous until delisted, an administrative process which may require months or years to complete. (Note: the state definition for F-listed waste is more stringent than the

b. Because the State of Maryland has not received mixed waste authorization from the EPA, classification and management of the hazardous component of mixed waste is conducted in accordance with the State's Controlled Hazardous Substance Regulations. 
federal definition which only applies the $10 \%$ volume criterion to the spent solvent before use.)

EPA also designated 123 discarded commercial chemical products as acute hazardous wastes (the P-listed wastes) and 249 other chemical products as hazardous wastes (the U-list wastes). To qualify as a listed waste under the $\mathbf{P}$ or $\mathrm{U}$ lists, the chemical product must be disposed of as an unused, commercially pure grade of the chemical (any technical grade of the chemical and all formulations in which the chemical is the sole active ingredient). However, if the chemical enters into a mixture or a reaction that is part of a laboratory process, the process waste is not a listed waste unless the process itself is listed (F- or Klisted wastes) or the waste exhibits hazardous characteristics (e.g., ignitability, corrosivity, reactivity, or toxicity characteristic). Thus, the mere addition of a reagent appearing on the lists of P- or U-chemicals, does not, by itself require that waste from that usage qualifies as a P- or U-listed waste. Wastes generated from these processes usually remain listed wastes.

In contrast to the F-listed solvents, NIH personnel have not encountered significant mischaracterization of process wastes as U-listed or P-listed wastes to date. No K-listed wastes are generated by biomedical research procedures.

It should also be emphasized that individual NIH laboratories generating wastes are not required to classify the wastes as described above. The laboratories are only required to indicate the generating process, and to list all of the hazardous constituents on the container label regardless of regulatory status of the wastes. Chemists from the NIH Chemical Recycling and Disposal Service determine the regulatory characterization.

Biomedical research procedures also generate waste containing hazardous constituents which are not regulated under RCRA, and some radioactive materials that are not regulated under AEA. Although mixed waste management standards are not applicable to such material, the potential risks posed by these wastes dictate that prudent management procedures with the same or greater precautions be applied. At NIH, unregulated, potentially hazardous mixed wastes are collected, labeled, tracked and handled in the same manner as regulated wastes. 


\subsection{LLMW GENERATOR INTERVIEWS}

The $20 \mathrm{NIH}$ LIMW generator interviews that were conducted are individually summarized in Appendix A. The interviewees were selected by examining the database of LLMW generation for the years 1989 to 1993 and identifying those laboratories that had generated the largest volumes of LLMW without readily available disposal options. The largest volumes of the more difficult-to-manage LLMW at NIH tended to be associated with usage of TCA, methanol, and acetic acid. In particular, TCA is used to denature proteins, useful for protein separations. Acetic acid, in association with methanol, is used in fixing and washing electrophoresis gels for DNA sequencing.

DNA sequencing waste typically consisted of fixes and washes of $10 \%$ TCA and $10 \%$ methanol, with past generation of up to 2 liters per DNA sequencing gel. This waste qualifies for regulation as a hazardous waste due to toxicity, corrosivity, the potential for ignitibility, and as a listed F003 waste (methanol). NIH wastes containing TCA are typically toxicity-characteristic RCRA wastes due to the presence of chloroform (D022). Research at NIH has confirmed that TCA, and its neutralization salts, continuously decarboxylate in the wastes to form chloroform.

Seven of the 20 generators interviewed were, or are, performing DNA sequencing. Each of these researchers described how waste volumes from gel fixing and washing have been reduced within the last year or two. For example, one generator no longer fixes and washes the gels in a 2 liter "bath" of acetic acid and methanol, but judiciously pours approximately $200 \mathrm{ml}$ of the fixative/wash over the gel. Another researcher reuses the same fix/wash bath for approximately 10 gels. Other researchers have switched to gels or techniques that can be used without fixing or washing with acetic acid and methanol, a practice that virtually eliminates the generation of LLMW from gel fixing and washing.

Another large-volume, potentially difficult-to-manage waste at NIH is generated from the use of automated HPLC equipment used to evaluate cell metabolism. This waste typically results from a series of cell culture extractions that are evaluated using a combination of liquid chromatography and LSC as described in Section 2.1. The resulting waste consists of a mixture of aqueous buffers (the carrier for the liquid chromatograph) and organic liquid scintillation cocktail (the counting medium for the liquid scintillation counter). LSC cocktails have typically included solvents such as toluene which, when discarded, were RCRA-listed wastes and/or were RCRA-characteristic wastes due to their low flashpoint. More recently, several vendors have offered LSC cocktails which include phenylxylylethane and/or long-chained alkylbenzene solvents that are not RCRA-listed wastes and have flashpoints sufficiently high that they are not RCRA-characteristic wastes. Depending on local permitting requirements, these cocktails can often be drain-disposed and are advertised as being "safe," "high flashpoint," and "biodegradable." 
The cocktails using newer toluene-free formulations do not appear to be more environmentally biodegradable than the earlier cocktail formulations using toluene. The use of the word "biodegradable" to describe these may be more of a promotional description than a description of their fate when released into the environment. Additionally, samples used with LSC cocktails can be mixed within a variety of solvents including toxic and ignitable compounds (e.g., methanol, acetonitrile). Because the hazardous solvent becomes mixed with the LSC cocktail during the analytical technique, the solvent and not the LSC cocktail would likely dictate if the waste could be drain disposable.

Most researchers are attempting to use these newer cocktails. However, the counting efficiency of some of these cocktails is lower than the older toluene-based LSC cocktails when they are used with ${ }^{3} \mathrm{H}$, which emits beta particles with a relatively low energy compared with other commonly used beta-emitters such as ${ }^{14} \mathrm{C}$. This is very dependent on other variables that can also affect the counting efficiency. Some LSC cocktail manufacturers claim that the ${ }^{3} \mathrm{H}$ counting efficiency of some of their newest biodegradable cocktails is better than the older toluene-based cocktails.

One researcher generated significant volumes of waste with chloroform extractions from cell cultures and subsequent washings with water, sodium borate, and acetic acid (approximately 5 gallons of $7 \%$ chloroform waste every month). Another cell culture laboratory used $10 \%$ TCA to stop a RT reaction followed by $100 \%$ methanol rinses. The researcher interviewed in this laboratory appeared frustrated because the TCA corroded a more modern cell harvester, requiring additional procedural steps and generation of approximately 12 times the waste volume of TCA and methanol. Current LLMW generation in this laboratory is approximately 15 gallons per month. ELISA (enzyme linked immuno sorbent assay), an alternative laboratory technique that generated less waste, can also be used to obtain the same result. However, it is a more expensive assay than the reverse transcriptase assay, if waste disposal costs are not considered.

Smaller volumes of difficult-to-manage LLMW at NIH are generated from silver staining in conjunction with radiolabeling of the protein. Mixed wastes from silver staining are typically a solution of ethanol, acetic acid, and water with the potential for a characteristic silver waste. As discussed in Section 2.1, another staining technique that generates mixed waste is staining with Coomassie Blue in conjunction with radiolabeling of the protein. With the Coomassie Blue stain the mixed waste contains a $30 \%$ methanol/10\% acetic acid solution, in addition to any radioactive contamination (typically ${ }^{32} \mathrm{P}$ or ${ }^{35} \mathrm{~S}$ ).

Small volumes of difficult-to-manage LLMW are also generated at NIH from other procedures. One example is the use of a phenol/chloroform mixture to extract isotopicallylabelled nucleic acids for subsequent analysis. As noted in Appendix A, this process appeared to produce a relatively small proportion of the total waste stream. 
Regarding steps to minimize waste, earlier efforts to educate the researchers in the importance of waste minimization appear to have had a significant impact on waste generation. Each researcher who was interviewed was genuinely concerned about the types and volumes of waste generated and eager to minimize generation of LLMW provided alternative methods produced valid research results. However, researchers expressed significant reluctance over the possibility of adopting an invalidated or unproven technique or substitution just to reduce mixed waste generation. Several researchers were concerned that a major change in protocol may require anywhere from 2 months to 2 years to repeat past work to validate and standardize the new technique or substitution. If a new technique was published in a peer-reviewed journal, however, the reluctance to adopt it was considerably less.

Gel fixing and washing, being the largest volume of difficult-to-manage LLMW, was the focal point of many generator interviews. The issue of whether or not to fix and wash electrophoresis gels for DNA sequencing appears to be as much a matter of individual preference and laboratory technique as an issue is driven by research needs. Table 3-1 summarizes some of the comments on the issue of whether or not to fix and wash the gels prior to autoradiography from different researchers performing DNA gel sequencing.

Table 3-1. Pros and cons of fixing and washing electrophoresis gels.

\begin{tabular}{ll}
\hline If Gels are Fixed... & If Gels are Not Fixed... \\
\hline $\begin{array}{l}\text { More certainty that the gel will transfer } \\
\text { correctly to the filter paper }\end{array}$ & $\begin{array}{l}\text { With care, the gel transfers to the filter paper } \\
\text { without incident }\end{array}$ \\
$\begin{array}{l}\text { Shorter drying time as gels dry faster without } \\
\text { the hydroscopic urea present }\end{array}$ & $\begin{array}{l}\text { Quicker and simpler procedure since less steps } \\
\text { are involved } \\
\text { Resolution may not be as good in the upper } \\
\text { regions of the plate }\end{array}$ \\
\hline
\end{tabular}

Another alternative to gel washing and fixing is the use of chemofluorescence coupled with automated equipment. It was apparent from the interviews that many researchers did not trust the results from automatic DNA sequencers except when the research became repetitive and standardized. Several researchers commented that for an occasional DNA sequence, it was far more reliable and less costly in terms of time, equipment, and labor to run the electrophoresis gel using traditional autoradiography than to standardize and calibrate the automated equipment. This alternative is discussed in greater depth in Section 4.1 of this report.

It also became apparent from generator interviews that equipment and chemical vendors play an important role in improving laboratory technique and waste minimization. Vendors promote alternative methodology and can invest the time required to validate a new 
technique, methodology, or new product or reagent. Several researchers were testing new products given them by vendors, although such testing was not a focal point of any of the research. Initial reports from researchers indicated that some of the products worked well, but several researchers were frustrated that the vendors considered some chemical constituents proprietary information.

In general, those interviewed stated that LLMW generation at NIH has been reduced over the past several years. Several reasons were given for waste reductions including the "maturation" of the research, development of techniques that used less radioactive material, and development of techniques that relied more on chemiluminescence instead of radioactivity. There was a general preference among many researchers to use nonradioactive techniques, if available and consistent with reliable research results.

The interviews indicate that minor procedural or process modifications require less costly validation and can generally be implemented with only a minor investment of time and lost research productivity. A bias towards minor modification is demonstrated by the fact that every researcher interviewed is using less acetic acid/methanol to fix and wash electrophoresis gels while very few researchers actually changed gels to avoid fixing and washing.

Some of the researchers are recycling waste materials within their laboratory when the same procedure is performed repetitively. However, in general, it appears that recycling opportunities are limited by both the precautions required for radioactive materials and by the lack of a simple, quick, and effective means of treating the waste reagents prior to their reuse. Recycling techniques do not appear to be any more effective at minimizing mixed waste generation than judicious and limited usage of gel fixing/washing solutions. 


\subsection{ASSESSMENT OF WASTE MINIMIZATION OPTIONS}

The information obtained from interviews with LLMW generators at the NIH was used to identify various waste minimization options. These options would reduce LLMW generation for research activities such as those conducted at the NIH. These options were identified and developed based on the approaches described in Section 2.2 and have, as their objective, a reduction in the quantity of LLMW generated rather than improvements in treatment and disposal of LLMW already generated. The waste minimization options are described and discussed below. Specific waste treatment and disposal options for previously generated waste are outlined in Section 5.0.

\subsection{Electrophoresis Gel Fixing/Washing Options}

Electrophoresis gels are one of the most powerful tools being used in biomedical research today. As discussed in Section 2.1, they are being used to separate proteins for identification, concentration, and/or analysis, to determine the peptide sequences in proteins (less commonly done now due to improvements in DNA sequencing), and to determine the sequence of bases in DNA. The development of these procedures required major breakthroughs to make them effective and they are unlikely to be discontinued until further breakthroughs occur that make possible improved alternative methods. A large proportion of the difficult-to-manage LLMW generated by biomedical research is produced through the use of electrophoresis gels with radiolabeled molecules. The following describes methods by which the volume of LLMW generated from electrophoresis gel usage might be reduced.

\subsubsection{Changes in Procedures}

Several methods for using electrophoresis gels exist that do not require the use of radiolabeled compounds or that require a much smaller volume of acid/methanol solution for fixing and washing the gels.

4.1.1.1 Elimination of Autoradiography. Nonradioactive alternatives exist to identify DNA and proteins in electrophoresis gels. As discussed in Section 2.2.1, ethidium bromide is frequently used as a dye for DNA detection. While it is useful in some applications, one drawback is that it does not work effectively with single-stranded DNA, which is often used in DNA sequencing studies. An additional difficulty is that ethidium bromide is a known mutagen and a suspected carcinogen and requires careful procedures to avoid exposure to laboratory workers. Coomassie Blue R-250 is often used to stain polypeptides separated by SDS-polyacrylamide gels. After staining, the proteins can be detected, photographed, and/or stored for further use.

Silver staining techniques are another alternative to autoradiographic techniques for both proteins and nucleic acids. As an alternative to radiolabeling, silver staining offers 
several advantages according to manufacturers of commonly used silver staining kits. It is more rapid, equivalent in sensitivity to autoradiography, less expensive, avoids altering the physical characteristics of proteins, and may detect proteins that are not detected in radiolabeled cell lysate. It also is claimed to offer advantages over Coomassie Blue R-250 staining agents due to its greater sensitivity and its ability to analyze dilute samples.

A final consideration is that the use of nonradioactive methods, such as those described here, can result in the generation of hazardous wastes that must be disposed of at an offsite RCRA treatment, storage, and disposal facility. LLMW minimization efforts must include consideration of the effect on waste volume, the total disposal costs, risks to workers, and other factors before recommending an option that substitutes the generation of RCRA hazardous waste for the generation of LLMW.

4.1.1.2 Reduction in Reagent Volumes. If autoradiography cannot be eliminated, the volume of reagents required to wash and fix electrophoresis gels can be significantly reduced, or fixing/washing steps can be eliminated or scaled down. When using DNA sequencing gels, the fixing/washing procedure that generates the largest volume of waste is soaking the gel after electrophoresis in a solution of $10 \%$ acetic acid and $10 \%$ methanol. Gel sizes used for DNA sequencing are typically quite large and require a significant volume of fixing solution of approximately 2 liters per gel. Some researchers have been able to reduce the volume of fixing solution by treating the surface of the gel rather than immersing the entire gel, or by reusing the fixing solution repeatedly. With measures such as these, the volume of fixing solution can be reduced by as much as $90 \%$ for each gel.

Some gels currently available can be used without performing the fixing step. One such gel is the "Long Ranger" gel provided by AT Biochem. This manufacturer states that the gel does not require fixing to remove urea prior to autoradiography using ${ }^{35} \mathrm{~S}$ labeled molecules. The manufacturer also states that the ${ }^{35} \mathrm{~S}$ signals are quenched by less than $20 \%$ without a fixing step resulting in both time savings and reduction in LLMW volume.

\subsubsection{Substitution of Reagents}

The reagents most commonly used in gel electrophoresis for gel fixing and washing are methanol, acetic acid, and TCA. In some cases, ethanol can be substituted for methanol. Ethanol has a much lower acute and chronic toxicity and would not produce a LLMW unless it were used in high enough concentrations to produce an ignitable-characteristic hazardous waste. Acetone can sometimes be substituted for TCA, methanol, or ethanol but does not represent an improvement because a waste acetone solution would still be a listed F003 hazardous waste. The Hazardous Solvent Substitution Data System (HSSDS) at the Idaho National Engineering Laboratory was investigated to determine if substitute reagents could be identified using its resources. No substitutions were found for methanol, trichloracetic acid, or acetic acid for biochemical applications such as gel fixing. 
Prompted by the waste minimization interviews, one group of researchers investigated alternative methods and materials for fixing and washing DNA sequencing gels. ${ }^{c}$ Previously, the laboratory used $10 \%$ acetic acid and $10 \%$ methanol to fix the DNA in the gel, reduce sample loss and diffusion, and remove urea, permitting proper drying of the gel prior to autoradiography. This group of researchers found that deionized water could be substituted for the $10 \%$ acetic acid and $10 \%$ methanol solution with indistinguishable results in the autoradiograph. When using deionized water, a 0.2 -mm-thick gel is washed for about 20 minutes. On very humid days the wash time needs to be lengthened to prevent the gel from sticking to the x-ray film. Alternatively, the gel could be covered with thin plastic wrap without affecting the quality of the sequencing data, even when ${ }^{35} \mathrm{~S}$ is used.

\subsubsection{Equipment Changes}

Much of the work with electrophoresis gels is being done for the purpose of determining the base sequences in DNA of interest. The volume of work in this area is so large that a number of companies have developed sophisticated automated DNA sequencing equipment. This automated equipment uses electrophoresis gels with laser activation of fluorescent dyes and subsequent computer scanning and interpretation of the signals in realtime. In the more advanced systems, a four-color dye system is used with one color specific to each of the four DNA bases by means of dye-labeled primers or dye-colored terminators. Laser activation of the dye during electrophoresis in conjunction with a photomultiplier tube produces a computer input signal that is interpreted and converted to a direct readout of the DNA base sequence. Such automated sequencing equipment has the potential to significantly reduce the volume of LLMW generated as a result of DNA sequencing activities. The cost of a complete automated scanner system is approximately $\$ 120,000$ depending on the selected options.

Typically, a facility using automated sequencing equipment sets up a "core" facility that includes the sequencers, computing equipment, and support facilities for preparing and processing the electrophoresis gels. The Institute for Genomic Research (TIGR) is one such facility. TIGR is a nonprofit research institute founded by several former NIH researchers that is currently operating 30 automated sequencers in pursuit of sequence-based characterization of gene expression (Adams et al. 1994). Researchers interviewed at NIH expressed reluctance to use automatic scanning equipment for intermittent and exploratory sequencing operations. However, for more standardized sequencing, the automated systems were highly desirable.

Another possible equipment change would be improving gel dryers. In some cases, fixing is required to remove urea to reduce the drying time of the gel and improve the dried

c. Memo dated November 3, 1994 from K. Usdin, Ph.D to Wm. Walker, Ph.D., Department of Health and Human Services, Public Health Service. 
gel handling characteristics. Improved gel drying equipment can sometimes be used to maintain drying time requirements while decreasing the quantity of reagent required for gel fixing by increasing the tolerance for urea in the finished gel.

\subsection{HPLC Scintillation Options}

HPLC scintillation counting is a powerful and widely used technique that has extensive value in identifying and characterizing unknown compounds. While most LLMW generated from HPLC has a disposal option, there are very few options for reducing the volume of LLMW generated from HPLC scintillation counting. As noted in Section 3.0, some scintillation fluids available that are claimed to be "biodegradablen and would not seem to be a listed or characteristic RCRA waste. However, one manufacturer of such a fluid recommends that it not be disposed to the sewage system due to its aquatic ecological toxicity. Other manufacturers claim that the EPA has performed aquatic toxicity testing on their fluids and approved them for drain disposal, subject to state and local discharge permits.

As noted previously, if solvents such as methanol or acetonitrile are used with LSC cocktails, the resultant waste would likely be regulated and would not be drain disposable. The composition of LSC cocktails is not usually known due to their proprietary nature; but, if they contain priority pollutants they would also be subject to drain disposal restrictions. Another option for LLMW volume reduction can come from careful attention to buffer flow rates during the running of an HPLC procedure. A flow rate higher than necessary can increase the volume of LLMW waste generated while not providing any increased research benefit.

\subsection{Blotting Options}

Several options exist for reducing LLMW during blotting activities. These are briefly described below.

\subsubsection{Use of Nonradiolabeled Molecules}

Several chemiluminescent reagents are available for use with blotting techniques that allow proteins to be detected without the radiolabeled molecules. Most of these use the horseradish peroxidase (HRP)-mediated luminol oxidation reaction in which the oxidation of luminol is catalyzed by peroxidase to produce light. Vendors claim that chemiluminescence offers advantages over radioactive methods due to its speed, sensitivity, and convenience. 


\subsubsection{Reagent Substitution}

Methanol and other reagents are frequently used in blotting techniques. Ethanol can be used in place of methanol in some systems for final membrane washing. This approach avoids generating a LLMW provided that the ethanol concentration is sufficiently low that an ignitable-characteristic waste is avoided. Another possible substitution involves the reagents used for the transfer buffer for the blotting. In western blotting, an older transfer procedure used an electrophoresis buffer consisting of tris-glycine electrophoresis buffer at a $\mathrm{pH}$ of approximately 8.3. This procedure typically requires approximately 12 hours to complete, but does not appear to produce a LLMW. In the newer procedure, a concentration of $20 \%$ methanol is used in the transfer buffer, which results in the generation of a LLMW. The advantage of the newer procedure, however, is that it is much more rapid and uses a smaller amount of electric current.

\subsubsection{Equipment Substitutions}

One vendor supplies a multi-purpose fluorescence scanner for gels and membranes that can be used as a substitute for radiolabeling techniques. The vendor claims that the system can be used to detect and quantify a variety of complex protein separations by using fluorescent dye kits specific to the test being performed. The system uses an argon scanning laser with a 50 micron scanning width that is combined with a photomultiplier tube and a computer analysis system. The time required for analysis is reduced from 72 hours for film autoradiography to as little as 2 hours with fluorescence. A drawback to the system is that the cost of the scanning system is approximately $\$ 57,000$.

\subsection{Options for Enzyme Assays/Cell Harvesting}

There are at least two options available for reducing waste generation in processing activities of this kind.

\subsubsection{Reagent Substitutions}

A nonradiometric test is available for the detection of RT. ${ }^{d}$ The manufacturer claims that the test has equal or greater sensitivity than the more commonly used ${ }^{3} \mathrm{H}$-based radiometric test and does not result in the generation of LLMW. The test costs approximately $\$ 400$ to $\$ 650$ and can be completed in 4 hours according to the manufacturer.

d. "RT-Detect" DuPont Medical Products. 


\subsubsection{Equipment Modifications}

In some cases, the provision of additional equipment can reduce the volume of LLMW generated. In cell harvesting, the same quantity of reagent is used for a 16-unit harvester or a 96-unit harvester due to the type of procedure being performed. However, the larger harvester processes six times more samples in a single batch resulting in the potential for a smaller total volume of LLMW generated.

\subsection{Options for Staining/Destaining}

Staining/destaining does not itself generate a mixed waste; however, a mixed waste is generated when staining/destaining is performed in addition to autoradiography. Therefore, the only option identified for reducing LLMW generation in conjunction with staining/destaining procedures is to use nonradiolabeled molecules. However, the use of radiolabeling is, to a high degree, specific to the particular project in progress. Therefore, the requirement for radiolabeling is determined by the other processing activities being used in combination with staining.

\subsection{Option Evaluations}

Evaluating waste minimization options generally includes the screening of options based on criteria such as efficacy, safety, short-term, long-term, and life-cycle costs, and estimates of potential waste reduction. Because many of the research applications were unique, no overall waste minimization screening methodology could be applied to the waste generating processes. Each process needs to be evaluated in relationship to its research purpose and the opportunities for waste reduction through material substitution, process change, equipment change, and waste segregation.

In addition to the microscopic review of each individual researcher's protocols, a macroscopic approach to the issues of short-term, long-term, and life-cycle costs should be considered at large institutions such as the NIH. While each of several departments may not have sufficient justification to purchase waste minimization or pollution prevention equipment involving large capital expenditures, taken together there may be sufficient utilization to warrant the expenditure. 


\subsection{WASTE TREATMENT OPTIONS}

Much of the waste produced by the processes described in Section 2.1 was determined to be difficult to manage at the time of the first NIH study (DOE/LLW-208) in 1993. Since that time, NIH has sent most of this waste to an offsite treatment facility, DSSI in Tennessee. NIH also treats and disposes of wastes using various methods that are able to process a larger proportion of the waste since 1993. Described below are in-house treatment technologies that can be applied to these previously generated wastes to create disposal options.

\subsection{Waste Stream Properties}

The results of a previous 1993 study (DOE/LLW-208) and the information obtained from generator interviews indicate that the waste produced by the processes described in Section 2.1 is relatively consistent in the physical and chemical properties that apply to treatment of the waste. The chemical reagents used in these processes are predominantly trichloroacetic acid, methanol, acetic acid, and ethanol. The concentrations of these reagents vary between 1 and 30 percent, with the exception of a small amount of 100 weight percent methanol used in the reverse transcriptase assay procedure described in Section 2.1.5. Other reagents that might be present in smaller quantities would be phosphoric acid and chloroform. The radioisotopes used are predominantly ${ }^{3} \mathrm{H},{ }^{14} \mathrm{C},{ }^{32} \mathrm{P}$, and ${ }^{35} \mathrm{~S}$.

Other reagents and compounds are also present in LLMW generated at the NIH, but would be found less frequently and at relatively low concentrations depending on the source of the waste. Examples of these would be phenol, silver compounds, acetonitrile, and pseudocumene. Biological materials, gel solids, surfactants, and other waste solids are commonly found in LLMW at NIH. Lipids and oils can also be present. These waste materials could have specific effects on waste treatment processes that would affect a proposed treatment strategy. Such effects might include clogging of filters by solids or increased turbidity.

The generated wastes containing these reagents would have some common physical and chemical properties. The wastes would be aqueous liquid wastes with small amounts of suspended solids present. The $\mathrm{pH}$ would likely be low enough that an adjustment would be required. Most of the organic reagents present are completely miscible in water though a few, such as chloroform, could form a separate organic layered phase. The concentration of organic reagents is likely to be high and could potentially be as high as 300,000 parts per million (ppm).

A number of treatment technologies exist that can provide treatment for waste streams with the reagents and properties described above. A preliminary screening of the feasibility of available treatment technologies was provided by using the information from the waste 
generating processes and generator interviews to develop a generic waste profile for the NIH LLMW. The majority of the LLMW, which was found to have no disposal options in the 1993 study (DOE/LLW-208), would fall within the parameters of this waste profile. To be effective, the proposed waste treatment technologies should be able to successfully treat wastes that lie within the generic waste profile. The composition and properties of this generic waste stream are identified in Table 5-1 below.

Table 5-1. Generic waste stream profile.

\begin{tabular}{lc}
\hline Reagents in Waste & Volume Percent \\
\hline Methanol & $0-30$ \\
Acetic acid & $0-10$ \\
Trichloroacetic acid & $0-10$ \\
Phosphoric acid & $0-1$ \\
Chloroform & $0-1$ \\
Ethanol & $0-5$ \\
Balance of Waste & \\
Water & $70-100$ \\
Ph & $1-4$ \\
Max. waste volume & 10,000 \\
(liters/year) & \\
Radionuclides in Waste & \\
${ }^{35} \mathrm{~S}$ & \\
${ }^{32} \mathrm{P}$ & \\
${ }^{3} \mathrm{H}$ & \\
${ }^{14} \mathrm{C}$ & \\
\hline
\end{tabular}

\subsection{Treatment Technologies/Processes}

Following pretreatment, disposal of the waste stream to the sanitary sewer system, described in Section 5.1, may be possible. The pretreatment objectives would be to remove compounds from the waste stream that prevent it from being discharged, increase the $\mathrm{pH}$ to acceptable discharge limits, and create a smaller secondary waste stream that could be transferred to a disposal outlet.

Except for chloroform, the reagent chemicals listed in Section 5.1 are miscible in water. With the exception of phosphoric acid, they are also organic compounds that are 
potentially subject to further oxidation. The ${ }^{32} \mathrm{P}$ and ${ }^{35} \mathrm{~S}$ radionuclides have relatively short half-lives and can be stored for decay prior to disposal.

Treatment technologies for this waste stream would be focused on removal or destruction of the organics and adjustment of the $\mathrm{pH}$ to acceptable discharge levels. Technologies for accomplishing these objectives are outlined below. NIH performs pretreatment activities and some of the treatment processes similar to those described here.

\subsubsection{Organics Removal}

The following sections describe several technologies for removing organics from the waste stream. Each technology is briefly evaluated for its applicability, feasibility, and effectiveness for the proposed application.

5.2.1.1 Phase Separation. The solvents used in liquid scintillation fluids, as well as chloroform, and other organics are immiscible in water and would exist as a second liquid phase if they were present along with the aqueous wastes described in Section 5.1. In this case, the nonpolar hydrophobic nonaqueous organic phase would separate from the aqueous phase lying below. This organic liquid phase could be separated and disposed of offsite at DSSI or by steam-reforming technology (Section 5.2.1.5). At NIH, phase separation is employed where feasible. However, emulsions are commonly encountered and difficult to separate. Surfactants are widely used in research procedures and contribute to emulsion formation.

5.2.1.2 Chemical Oxidation. The most commonly used chemical oxidation process for wastewater uses UV light and hydrogen peroxide to oxidize organic compounds to carbon dioxide and water. The UV light activates organic molecules making them more amenable to oxidation, and assists in the creation of hydroxyl radicals from the hydrogen peroxide. The hydroxyl radicals are powerful oxidants that then act on the organic molecules present to produce carbon dioxide and water. Chlorinated compounds will contribute some acidity to the water requiring adjustment of the $\mathrm{pH}$.

The hydrogen peroxide is added to the influent stream and the mixture is passed through a closed vessel equipped with powerful lamps that generate light energy in the UV range of the spectrum. Typically, versions of this technology that use high-intensity lamps operate continuously at ambient temperature and require residence times of 1 to 5 minutes to effect near-complete oxidation of most organic compounds. An advantage of chemical oxidation is that no secondary waste is produced because organics are completely oxidized. The high concentration of the organics in the anticipated waste stream would require a recirculating water stream to which the waste would be slowly added to maintain an influent organics concentration in the desired range. 
NIH has completed testing of a UV-enhanced chemical oxidation system and has successfully placed a unit into service. A feature of the NIH system is recirculation of the treated waste. The recirculation flow is controlled based on the oxidant concentration, not the concentration of organics. Process control is by measurement of the peroxide concentrations. A possible advantage of a UV oxidation system is that it may sterilize the waste, eliminating any potentially biohazardous agents. However, there is no data currently available on effects of this type.

5.2.1.3 Carbon Adsorption. Commercially available granulated activated carbon (GAC) is often used to adsorb organics contained in aqueous feed streams. GAC can also be partially effective in adsorbing selected inorganic radionuclides. GAC is most effective when used to adsorb relatively high-molecular-weight hydrocarbons that exhibit low solubility in aqueous solution. GAC is not as effective in adsorbing many types of organics such as some types of chlorinated hydrocarbons and polar solvents such as acetone or methanol. The GAC has a limited capability for adsorbing organic molecules. When this limit is reached, the organics will pass through the GAC bed in a condition referred to as "breakthrough." When this occurs, the GAC must be removed from the adsorption vessel and replaced with fresh GAC. The spent GAC can be reactivated or disposed of as a waste.

A drawback to using GAC for the anticipated waste stream is that the adsorption capacity of the GAC for the anticipated organic compounds is low and the potential organic loading is proportionately high. This might result in a large waste volume of spent GAC relative to the size of the initial waste stream. The spent GAC would become a mixed waste that would have to be disposed if it was used to treat a listed waste, or if it exhibited a RCRA waste characteristic such as chloroform toxicity (DO22).

NIH uses a GAC system to process aqueous waste streams to remove chloroform and has found it to be quite effective. No facility currently exists to accept mixed waste GAC for reactivation. Land disposal of spent GAC may be possible but would depend on its EPA waste designation, treatment to land disposal restrictions, and the degree of radioactivity that it exhibited. The potentially large volume of spent GAC that could be produced and the limited treatment and disposal outlets for this secondary waste limit the feasibility of GAC as a LLMW treatment technology.

5.2.1.4 Solvent Extraction. The high concentrations of organics in the anticipated waste stream could be removed via extraction with a solvent selected for the purpose. The extraction solvent would be a nonpolar organic compound with a low solubility in water. It would be contacted countercurrently with the waste stream in a liquid/liquid contacting vessel where the organic reagent chemicals would be transferred out of the aqueous phase and into the extraction solvent phase. Solvent extraction would be technically difficult for some of the organics anticipated to be present and would require extensive additional pretreatment and post-treatment of the waste stream. In addition, a solvent recovery system would be 
required to recover solvent from the extracted organic wastes. The extracted organics could be disposed of via offsite incineration, steam reforming, or other thermal or nonthermal destruction technology.

Recycling of recovered organics is a possible treatment approach if influent waste streams could be segregated by reagent chemical and processed in a sequential fashion. The recovered organics would still contain radioactive materials and would require management as a mixed waste. Depending on the specific conditions, the aqueous waste portion might also contain radioactive materials and require management as a LLW. These difficulties make it doubtful that solvent recovery would significantly reduce the volume of LLMW and it is not considered to be a viable treatment technology.

5.2.1.5 Steam Reforming. Steam reforming is a technology for chemically converting organic wastes to $\mathrm{CO}, \mathrm{H}_{2}, \mathrm{CO}_{2}, \mathrm{H}_{2} \mathrm{O}$, and $\mathrm{CH}_{4}$ by using steam reforming chemistry. In steam reforming, reforming reactions occur in a near oxygen-free environment under high pressure and temperature and allow an extremely high conversion of organics to the primary conversion products of $\mathrm{CO}_{2}, \mathrm{H}_{2} \mathrm{O}$, and $\mathrm{H}_{2}$. A significant advantage is that the process can be used to convert organic compounds contained within a solid matrix, thus allowing the processing of mixed waste forms such as GAC that are not presently treatable using conventional incineration or combustion treatment. The steam reforming process requires specialized equipment that is not commercially available for installation at a location such as the NIH. Scientific Ecology Group, Incorporated (SEG) in Oak Ridge, Tennessee, is currently developing a commercial mixed waste treatment facility using this technology. One possible advantage of steam reforming is that it may sterilize the waste, eliminating any potentially biohazardous agents. However, there is no data currently available on effects of this type.

\subsection{2 pH Adjustment}

Following and/or preceding treatment, the $\mathrm{pH}$ of the aqueous waste stream would require adjustment to meet anticipated discharge requirements. The $\mathrm{pH}$ would be increased with the addition of sodium hydroxide and would be decreased, if required, with sulfuric acid. The $\mathrm{pH}$ adjustment would be performed in mixing tanks that preceded and followed the organics removal process. The $\mathrm{pH}$ adjustment would be controlled via metering pumps and pH control equipment.

\subsection{Proposed Treatment Process}

The recommended organics removal process would be physical phase separation followed by chemical oxidation. Chemical oxidation is recommended based on its demonstrated ability to remove organics from water and on its ability to effectively treat the waste stream without producing a secondary waste. As noted in Section 5.2.1.2, NIH has 
installed a UV-enhanced chemical oxidation system. The recommended process arrangement is shown on Figure 5-1. Following phase separation, the influent concentrated waste stream would be mixed with a recirculating water stream to create a combined waste stream with an organics concentration suitable for the UV oxidation reactor system. The two streams would be combined in a mixing tank and the $\mathrm{pH}$ would be adjusted, as required, to obtain optimum conditions for oxidation. Following the oxidation of the organics, the combined stream would enter a second $\mathrm{pH}$ adjustment tank where the $\mathrm{pH}$ would be increased to meet final effluent discharge requirements. A portion of the final treated effluent would be discharged and the remainder would be recycled to be combined with additional concentrated influent waste. A scrubbing system might be required for the offgas from the UV oxidation system depending on site requirements and final operating conditions. The scrubbing system could also be used to reduce ${ }^{3} \mathrm{H},{ }^{14} \mathrm{C}$, and aerosols, if required. Monitoring of effluent and offgas concentrations for radioactivity and processing effectiveness would be required. Additionally, a RCRA permit is required for such a treatment facility. 


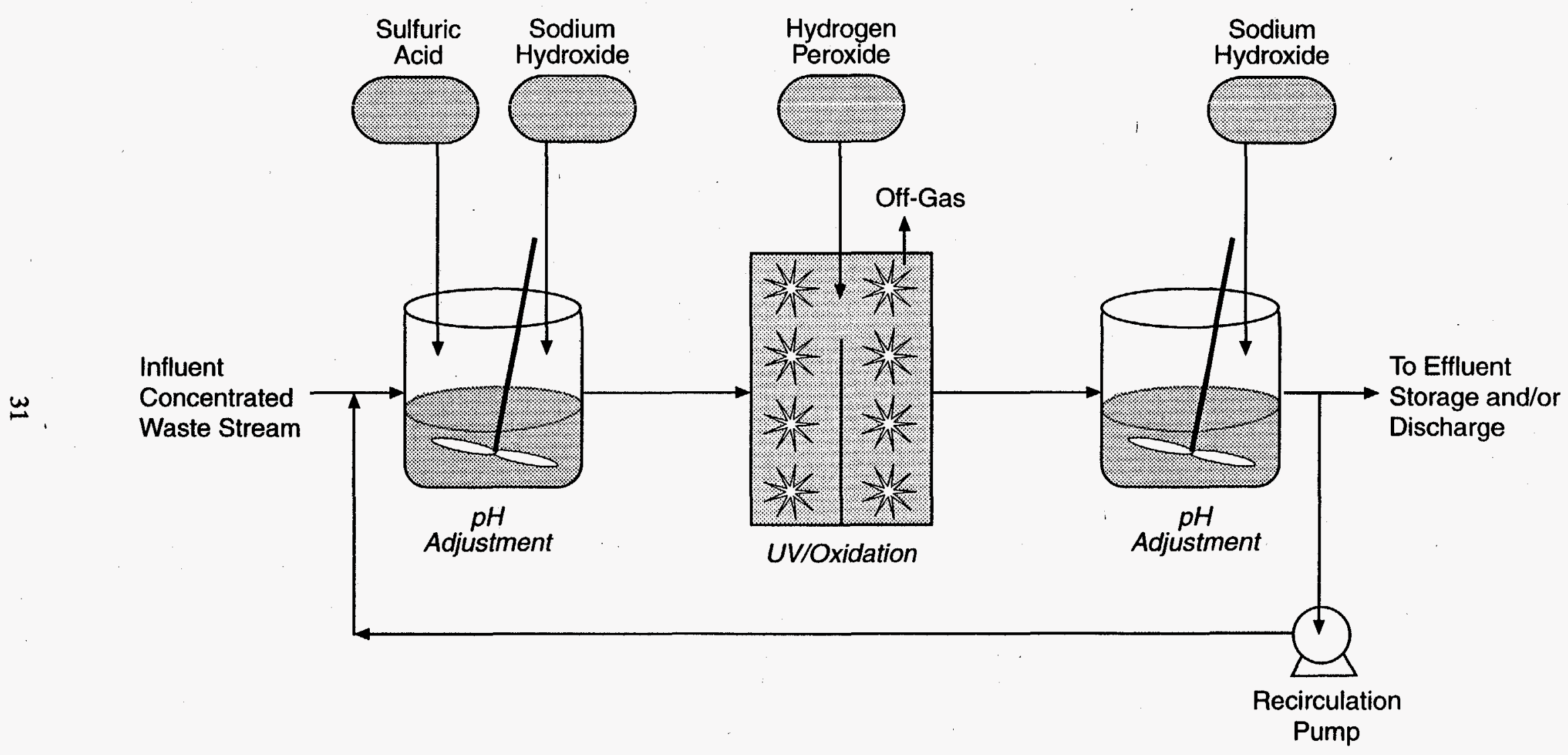

Figure 5-1. Recommended process for organic LLMW treatment. 


\subsection{CONCLUSIONS AND RECOMMENDATIONS}

The largest quantities of LLMW evaluated for this study are associated with a relatively small number of research techniques and processes, namely, gel electrophoresis, HPLC/scintillation counting, cell harvesting, staining and destaining, and protein blotting. Researchers generating LLMW from these processes were interviewed to obtain information that might suggest generally applicable waste minimization techniques. Virtually all generators who were interviewed have reduced LLMW generation rates from previous years; however, most of the waste minimization efforts were the result of either minor process changes in research protocol or a maturation of the research effort whereby more focused studies are now pursued.

Just as each area of research is uniquely pursued, each of the waste minimization options needs to be evaluated in the context of the particular research application. No panacea or generally applied procedure can be used to minimize the LLMW from each generating process. Nonetheless, generalizations regarding greater or less suitability can be made for each generating process and each type of waste minimization option. Based on the analysis outlined in Section 4.0, Table 6-1 summarizes waste minimization option feasibility.

Table 6-1. Summary of feasibility of waste minimization options.

\begin{tabular}{|c|c|c|c|c|c|}
\hline & $\begin{array}{l}\text { Substitution } \\
\text { of Reagents }\end{array}$ & $\begin{array}{l}\text { Minor Changes } \\
\text { in Techniques }\end{array}$ & $\begin{array}{l}\text { Improved } \\
\text { Waste } \\
\text { Segregation }\end{array}$ & Recycling & $\begin{array}{l}\text { Changes in } \\
\text { Equipment }\end{array}$ \\
\hline $\begin{array}{l}\text { Gel Fixing/ } \\
\text { Washing }\end{array}$ & - & - & - & - & - \\
\hline $\begin{array}{l}\text { HPLC } \\
\text { Scintillation } \\
\text { Counting }\end{array}$ & - & - & - & - & - \\
\hline Blotting & - & - & $=$ & - & - \\
\hline Cell Harvesting & - & - & - & - & 0 \\
\hline $\begin{array}{l}\text { Staining/ } \\
\text { Destaining }\end{array}$ & 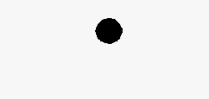 & - & - & - & - \\
\hline $\begin{array}{ll}\text { - } & \text { Not consi } \\
\text { - } & \text { Limited f } \\
& \text { Likely fea }\end{array}$ & $\begin{array}{l}\text { d feasible. } \\
\text { ilitity. } \\
\text { e. }\end{array}$ & & & & \\
\hline
\end{tabular}

The analysis also indicates that these unique research applications inhibit formal evaluation of waste minimization options on a facility-wide basis. Evaluating waste minimization options generally includes the screening of the options based on criteria such as safety, short- and long-term and life cycle costs, and estimates of potential waste reduction. 
Due to the uniqueness of each area of research, waste generation, cost, and implementation procedures differed significantly for each waste stream in a particular research area. Accordingly, no facility-wide waste minimization option screening could be applied to a particular waste stream.

Based on generator interviews, independent evaluation of LLMW generating processes, and the analysis of waste minimization options contained in the previous sections, the following additional conclusions are made:

- Most of the reagents that are used do not appear to have substitutes acceptable to the research community at this time. This situation is particularly true for TCA and methanol. However, there do appear to be substitution opportunities for using alternative gels that would require either a smaller volume of fixatives or would not require fixing or washing.

- Procedural changes appear to be a potential waste minimization approach for some research applications. In particular, chemiluminescent detection techniques could be used more widely as a substitute for techniques involving autoradiography. Also, additional expenditures for new equipment could reduce waste volumes. Such equipment might include 96-unit cell harvesters instead of 12-unit harvesters, automated DNA sequencers, and gel dryers, all of which were identified by researchers as having the potential to reduce waste volumes. Established project protocols, however, tend to limit the application of newer techniques in the near term. Additionally, funding arrangements limit the ability of an individual researcher to unilaterally obtain such equipment.

- There does not appear to be significant opportunities for LLMW volume reduction by segregation of radioactive and hazardous waste streams. The techniques being used require the contacting of reagents with radioactive materials with the resultant transfer of radioactive materials to the reagent waste. The researchers interviewed already strive to segregate radioactive waste from nonradioactive wastes.

- The NIH radiation safety group appears to have done a good job of educating and informing the generators about the additional expense and effort required to manage mixed waste, including the need to segregate radioactive and nonradioactive wastes. However, additional efforts in the area of generator education should be pursued. One possible mechanism would be more interdisciplinary seminars on techniques for laboratory waste minimization. 
- $\quad$ Recycling opportunities are limited by both the precautions required for radioactive materials and by the lack of a simple, quick, and effective means of treating the waste reagents prior to their reuse.

- The waste produced by gel electrophoresis and filter washing techniques appears to be surprisingly uniform in character and composition, regardless of the specific research application. Such uniformity makes treatment options a potentially effective means of reducing LLMW volumes requiring disposal. Such techniques as stabilization and biotreatment of portions of the LLMW waste streams at the NIH appears to be a possibility if conducted in conjunction with other waste treatment options.

- An opportunity may exist for LLMW minimization through improved waste characterization. Experience to date has indicated that laboratories may be overestimating solvent concentrations, thus resulting in a mischaracterization of the hazardous component of some LLMW as an F-listed spent solvent, instead of an ignitable characteristic waste. The treatment residues of listed wastes require disposal as a hazardous waste.

Wastes for which treatment is not readily available are generally aqueous with organic concentrations of up to $30 \%$, often having $\mathrm{pH}$ less than 4 , and contamination with ${ }^{3} \mathrm{H},{ }^{14} \mathrm{C}$, ${ }^{32} \mathrm{P}$, and ${ }^{35} \mathrm{~S}$. Recommended treatment for these wastes consists of a RCRA-permitted pretreatment facility involving a combination of storage for decay, organic recovery from multi-phase waste containers, waste aggregation in mixing tanks, adjustment of $\mathrm{pH}$, treatment by chemical UV oxidation, and final adjustment of $\mathrm{pH}$ prior to release. Recovered organics would be treated by offsite incineration or other thermal destruction process. Offgases would be monitored, and if necessary, treated for limited removal of radioactive contaminants. Most of the effluent would be aqueous, releasable to the sanitary sewerage system following successful operation of the treatment facility.

This evaluation of the more difficult-to-treat LLMW from biomedical processes demonstrates that much of the biomedical LLMW can be reduced, if not eliminated, and that which cannot be reduced further can likely be treated to an effluent that is releasable to the sanitary sewerage system. 


\subsection{REFERENCES}

Adams et al., "A Model for High Throughput Automated DNA Sequencing and Analysis," Nature Vol. 368, March 31, 1994.

DOE, National Low-Level Waste Management Program, National Institutes of Health: Mixed Waste Stream Analysis, DOE/LLW-208, 1994.

EPA, Waste Minimization Opportunity Manual, EPA/62/7-88/003.

Party, E. and E. L. Gershey, "A Review of Some Available Radioactive and Non-Radioactive Substitutes for Use in Biomedical Research," Health Physics Vol. 69, Number 1, July 1995. 
APPENDIX A

SUMMARY OF GENERATOR INTERVIEWS

A-1 
A-2 


\section{APPENDIX A SUMMARY OF GENERATOR INTERVIEWS}

The 20 NIH LICMW generator interviews that were conducted are summarized in this appendix. This information identifies the researcher by number sequence of interview, a brief description of the waste generation process as described in Section 2.1 in the main report, previous generation practices based on information in the LLMW database, and a brief description of current or future generation processes. Because either the nature of the research has changed or the waste generation techniques have changed, this more recent waste generation information was sought. Emphasis was placed on those wastes that do not have a readily available means of disposal, primarily the aqueous wastes with relatively high organic content. 
Appendix A. Summary of generator interviews.

Page 1 of 8

\begin{tabular}{|c|c|c|c|}
\hline $\begin{array}{l}\text { Researcher } \\
\text { Number }\end{array}$ & Process Descriptions & Previous Generation & $\begin{array}{c}\text { Current Generation/ Waste } \\
\text { Minimization }\end{array}$ \\
\hline 1. & $\begin{array}{l}\text { Gel fixing/washing for } \\
\text { DNA sequencing }\end{array}$ & $\begin{array}{l}2 \mathrm{~L} \text { of } 10 \% \text { acetic acid/ } \\
10 \% \text { methanol per gel for } \\
\text { fixing/washing }\end{array}$ & $\begin{array}{l}90 \% \text { volume reduction } \\
\text { achieved by using less } \\
\text { fixing/washing solution. }\end{array}$ \\
\hline \multirow[t]{3}{*}{2.} & $\begin{array}{l}\text { Protein separation gel } \\
\text { fixing/washing with }{ }^{32} \mathrm{P} \text { for } \\
\text { autoradiography }\end{array}$ & $\begin{array}{l}\text { Trichloroacetic acid (TCA) } \\
\text { and } 66 \% \text { ethanol about } \\
1 \text { liter per week }\end{array}$ & $\begin{array}{l}\text { No significant change. } \\
\text { TCA waste is being } \\
\text { generated with improved } \\
\text { segregation. Ethanol usage } \\
\text { is } 95 \% \text { pure. }\end{array}$ \\
\hline & - & $\begin{array}{l}{ }^{3} \mathrm{H} \text { Borohydride reactions } \\
\text { with dimethylformamide as } \\
\text { solvent }\end{array}$ & No change. \\
\hline & Protein labeling with ${ }^{35} \mathrm{~S}$ & Silver staining kit & $\begin{array}{l}\text { No change. This waste, } \\
\text { while not necessarily a } \\
\text { RCRA-regulated waste, is } \\
\text { nonetheless managed as a } \\
\text { hazardous waste at NIH. }\end{array}$ \\
\hline \multirow[t]{2}{*}{3.} & $\begin{array}{l}\text { DNA sequencing with }{ }^{32} \mathrm{P} \\
\text { for autoradiography }\end{array}$ & $\begin{array}{l}\text { Gels fixed with TCA and } \\
\text { methanol }\end{array}$ & $\begin{array}{l}\text { Eliminated generation of } \\
\text { LLMW by switching to } \\
\text { different gel, Long } \\
\text { Ranger }{ }^{\mathrm{m}} \text {, which does not } \\
\text { require fixing and washing. }\end{array}$ \\
\hline & $\begin{array}{l}\text { Protein separations with } \\
{ }^{14} \mathrm{C}\end{array}$ & $\begin{array}{l}100 \% \text { acetic acid fix, then } \\
\text { rinse with a moderately } \\
\text { toxic solvent (PPO) }\end{array}$ & $\begin{array}{l}\text { Considering the use of } \\
\text { DuPont's Entensify } \\
\text { Initial fix with } 10 \% \text { acetic } \\
\text { acid and } 30 \% \text { methanol; } \\
\text { then addition of } \\
\text { proprietary Solutions A } \\
\text { and B (contains halogens } \\
\text { and is managed as } \\
\text { radioactive mixed waste). } \\
\text { This procedure generates } \\
4 \text { liters per month which is } \\
\text { more LLMW than the } \\
\text { procedure with the toxic } \\
\text { solvent. The laboratory } \\
\text { technician preferred } \\
\text { Entensify due to } \\
\text { improved occupational } \\
\text { safety. }\end{array}$ \\
\hline
\end{tabular}


Appendix A. Summary of generator interviews.

Page 2 of 8

\begin{tabular}{ll}
\hline $\begin{array}{c}\text { Researcher } \\
\text { Number }\end{array}$ & Process Descriptions \\
\hline 4. & $\begin{array}{l}\text { Previously gel fixing/ } \\
\text { washing } \\
\text { Binding assays with }{ }^{3} \mathrm{H}\end{array}$ \\
& \\
& Kinase assays with ${ }^{32} \mathrm{P}$ \\
& \\
& $\begin{array}{l}\text { Amino acid and protein } \\
\text { synthesis with LSC }\end{array}$
\end{tabular}

Protein separation for autoradiography

$55 \%$ ethanol washes (25 ml ethanol per sample) one carboy per year of ${ }^{3} \mathrm{H}$ waste

${ }^{32} \mathrm{P}$-labeled enzyme is denatured with TCA, sulfacylic acid, or phosphoric acid generating four carboys per year of ${ }^{32} \mathrm{P}$ characteristic waste

With ${ }^{35}$ S: $10 \%$ TCA to precipitate and wash protein, acetone to reduce quench for improved LSC counting ( $10 \mathrm{ml}$ of $10 \%$ $\mathrm{TCA}+2 \mathrm{ml}$ acetone per filter). Annual generation is one to five carboys per year.

Gel fixing used acetic acid, and $5 \%$ ethanol for drying ( $-20 \mathrm{ml}$ per gel).
Current Generation/ Waste Minimization

No longer doing gel fixing and washing.

Optimized volume of ethanol.

Kinase assay waste can be neutralized.

Lab is now using less TCA, and segregating long/short half-life radionuclides better.

No LLMW generation, as the lab is currently not fixing the gel; using Acrylease (a silicon spray) to improve transfer of gel from plate. 


\begin{tabular}{|c|c|c|c|}
\hline $\begin{array}{l}\text { Researcher } \\
\text { Number }\end{array}$ & Process Descriptions & Previous Generation & $\begin{array}{c}\text { Current Generation/ Waste } \\
\text { Minimization }\end{array}$ \\
\hline \multirow[t]{3}{*}{6.} & $\begin{array}{l}\text { Protein precipitation with } \\
\text { LSC }\end{array}$ & $\begin{array}{l}\text { With }{ }^{35} \text { S uses } 10 \% \text { TCA } \\
\text { for precipitating proteins; } \\
\text { protein collected on } \\
\text { nitrocellulose filters, then } \\
\text { washed } 3 \text { times with } \\
\text { approximately } 2 \text { ml TCA } \\
\text { Filter dried and counted in } \\
7 \text { ml LSC vial. Previous } \\
\text { generation } 180 \text { liters per } \\
\text { year. }\end{array}$ & $\begin{array}{l}\text { In general, using more } \\
\text { immunofluorescence } \\
\text { antibodies instead of } \\
\text { radiolabels, but images do } \\
\text { not appear as sharp as } \\
\text { when the procedure was } \\
\text { performed.with } \\
\text { radioactivity. }\end{array}$ \\
\hline & $\begin{array}{l}\text { DNA hybridization with } \\
\text { autoradiography }\end{array}$ & $\begin{array}{l}\text { DNA is hybridized using } \\
\text { 32 P-labeled oligoprobe. } \\
\text { Add } 10 \mathrm{ml} 50 \% \text { formamide } \\
\text { solution to denature DNA. } \\
\text { This waste is managed as } \\
\text { LLMW, even though it is } \\
\text { not strictly regulated as } \\
\text { such. }\end{array}$ & $\begin{array}{l}\text { Lab now uses less activity } \\
\text { in the oligoprobe primer, } \\
\text { now } \sim 1.5 \mu \mathrm{Ci} \text { per reaction. }\end{array}$ \\
\hline & $\begin{array}{l}\text { Gel fixing for DNA } \\
\text { sequencing with } \\
\text { autoradiography. }\end{array}$ & None & $\begin{array}{l}\text { Directly transferring gel to } \\
\text { paper, thereby generating } \\
\text { no LLMW. }\end{array}$ \\
\hline 7. & $\begin{array}{l}\text { Gel fixing for sequencing } \\
\text { nucleic acids and } \\
\text { separating proteins } \\
\text { (Western Blots) }\end{array}$ & $\begin{array}{l}\text { Uses } 5 \% \text { methanol, } 10 \% \\
\text { acetic acid solution for } \\
\text { fixing and washing } \\
\text { proteins. Previously } \\
\text { generated } 5 \text { gallons } / 2 \\
\text { weeks. }\end{array}$ & $\begin{array}{l}\text { Seeking an automatic } \\
\text { sequencer using chemi- } \\
\text { fluorescence for some } \\
\text { analyses. Also contracting } \\
\text { some sequencing to } \\
\text { contractor laboratories. }\end{array}$ \\
\hline 8. & $\begin{array}{l}\text { High Performance Liquid } \\
\text { Chromatography (HPLC) } \\
\text { with }{ }^{3} \mathrm{H},{ }^{14} \mathrm{C}\end{array}$ & $\begin{array}{l}\text { HPLC process varies } \\
\text { amounts of } 0.02 \mathrm{M} \text { Buffer } \\
\mathrm{A}(0 \% \text { methanol and } \\
\text { ammonium phosphate) and } \\
0.7 \mathrm{M} \text { Buffer } \mathrm{B}(10 \% \\
\text { methanol and } \mathrm{pH}-5 \text { or } \\
6 \text { ). Process results in less } \\
\text { than } 5 \% \text { methanol in waste } \\
\text { jug. Waste contains } 35 \% \\
\text { ammonium phosphate and } \\
60 \% \text { Monofluor4 [a liquid } \\
\text { scintillation counting } \\
\text { (LSC) fluor]. This lab also } \\
\text { manages ammonium } \\
\text { formate buffer as LLMW. } \\
\text { Previous generation was } 5 \\
\text { to } 10 \text { gallons per week of } \\
\text { HPLC waste. }\end{array}$ & $\begin{array}{l}\text { Switched to Monofluor } 4 \text {, a } \\
\text { non-RCRA regulated LSC } \\
\text { fluor. }\end{array}$ \\
\hline
\end{tabular}




\begin{tabular}{|c|c|c|c|}
\hline $\begin{array}{l}\text { Researcher } \\
\text { Number }\end{array}$ & Process Descriptions & Previous Generation & $\begin{array}{c}\text { Current Generation/ Waste } \\
\text { Minimization }\end{array}$ \\
\hline \multirow[t]{3}{*}{9.} & $\begin{array}{l}\text { DNA sequencing with } \\
\text { autoradiography }\end{array}$ & $\begin{array}{l}\text { Approximately } 1 \text { liter of } \\
10 \% \text { methanol and } 10 \% \\
\text { acetic acid solution for gel } \\
\text { fixing/washing. }\end{array}$ & $\begin{array}{l}\text { Now use less fixer to just } \\
\text { wet the surface of the gel. } \\
\text { Filter is laid directly on } \\
\text { top of gel and lifted off. } \\
\text { Approximately } 90 \% \text { of } \\
\text { waste volume reduced by } \\
\text { this technique. }\end{array}$ \\
\hline & & & $\begin{array}{l}\text { Automatic sequencer is } \\
\text { used when the research is } \\
\text { standardized and repetitive. } \\
\text { Not cost or time effective } \\
\text { for smaller number of gels. }\end{array}$ \\
\hline & $\begin{array}{l}\text { Protein separations using } \\
\text { staining solution }\end{array}$ & $\begin{array}{l}\text { Uses } 10 \% \text { acetic acid and } \\
40 \% \text { methanol for fixing. }\end{array}$ & $\begin{array}{l}\text { Nonradioactive staining } \\
\text { procedure does not } \\
\text { generate LLMW, except } \\
\text { when used in addition to } \\
\text { autoradiography. Because } \\
\text { protein gels are small, little } \\
\text { LLMW is generated per } \\
\text { gel. }\end{array}$ \\
\hline \multirow[t]{5}{*}{10.} & $\begin{array}{l}\text { DNA sequencing with } \\
\text { autoradiography }\end{array}$ & $\begin{array}{l}\text { Uses }{ }^{35} \mathrm{~S} \text { and }{ }^{32} \mathrm{P} \text { with } \\
\text { large polyacrylamide gels; } \\
\text { acetic acid and methanol } \\
\text { fix/wash. }\end{array}$ & $\begin{array}{l}\text { Can reuse one liter of } \\
\text { wash/fixate for about } \\
10 \text { gels. (This was the only } \\
\text { researcher who claimed to } \\
\text { recycle gel washes/fixes) }\end{array}$ \\
\hline & $\begin{array}{l}\text { Phenol/chloroform } \\
\text { extractions }\end{array}$ & $\begin{array}{l}\text { Uses }{ }^{32} \mathrm{P} \text { in } 100 \text { tubes for } \\
\text { each run. Generates } \\
\text { approximately } 100 \mu \mathrm{l} \text { water } \\
\text { and } 200 \mu 195 \% \text { ethanol } \\
\text { waste per run. }\end{array}$ & $\begin{array}{l}\text { Potential for better waste } \\
\text { segregation between } \\
\text { aqueous and organic. }\end{array}$ \\
\hline & RNA-sol & $\begin{array}{l}\text { Generates waste containing } \\
\text { chloroform, phenol, and } \\
\text { alcohol. }\end{array}$ & $\begin{array}{l}\text { Segregated and managed as } \\
\text { mixed waste. }\end{array}$ \\
\hline & Cell extractions with LSC & Various organic solvents. & $\begin{array}{l}\text { Segregated and managed as } \\
\text { mixed waste. }\end{array}$ \\
\hline & HPLC & $\begin{array}{l}\text { Potential for acetonitrile in } \\
\text { waste in addition to LSC } \\
\text { fluor and buffers. }\end{array}$ & No change in procedure. \\
\hline
\end{tabular}


Appendix A. Summary of generator interviews.

Page 5 of 8

\begin{tabular}{|c|c|c|c|}
\hline $\begin{array}{l}\text { Researcher } \\
\text { Number }\end{array}$ & Process Descriptions & Previous Generation & $\begin{array}{l}\text { Current Generation/ Waste } \\
\text { Minimization }\end{array}$ \\
\hline \multirow[t]{4}{*}{11.} & Gel fixing/washing & $\begin{array}{l}\text { Uses }{ }^{32} \mathrm{P} \text { fixing with } 40 \% \\
\text { methanol and } 10 \% \text { acetic } \\
\text { acid; previously generated } \\
\text { approximately } 1 \text { liter per } \\
\text { gel. }\end{array}$ & $\begin{array}{l}\text { Previously had large } \\
\text { volumes of gel fixate and } \\
\text { wash and silver staining of } \\
\text { gels. Now using an } \\
\text { antibody to isolate protein } \\
\text { and generating only a small } \\
\text { amount of LLMW. }\end{array}$ \\
\hline & Silver staining & $\begin{array}{l}\text { Silver staining waste } \\
\text { consisted of } 200 \mathrm{ml} \\
\text { oxidizer, } 100 \mathrm{ml} \text { silver } \\
\text { stain, } 500 \mathrm{ml} \text { silver reagent, } \\
600-1,000 \mathrm{ml} \text { developer. }\end{array}$ & $\begin{array}{l}\text { When used in conjunction } \\
\text { with antibody technique, } \\
\text { no LLMW is generated. }\end{array}$ \\
\hline & HPLC & $\begin{array}{l}\text { Aqueous and organic waste } \\
\text { solutions resulting from } \\
\text { multiple extractions and } \\
\text { LSC analysis. }\end{array}$ & $\begin{array}{l}\text { HPLC uses a smaller } \\
\text { volume of Flo Scint } \\
\text { scintillation cocktail than } \\
\text { equivalent manual } \\
\text { technique. }\end{array}$ \\
\hline & Other activities & $\begin{array}{l}\text { Waste also contains } \\
\text { perchloric acid } \\
\text { (hydrolyses/destroys ATP), } \\
\text { molybdate (precipitates } \\
\text { phosphate), triethylamine } \\
\text { (buffer), and acetone } \\
\text { (precipitates protein). } \\
\text { Lipid extractions involve } \\
50{ }^{\circ} \mathrm{Ci}{ }^{3} \mathrm{H} \text { and }{ }^{14} \mathrm{C} \text { with } \\
\text { acetone (pure) or } \\
\text { chloroform/methanol }(50 \% \\
\text { concentration) }\end{array}$ & $\begin{array}{l}\text { No specific waste } \\
\text { minimization techniques } \\
\text { were employed or } \\
\text { suggested for these } \\
\text { relatively infrequent } \\
\text { processes. }\end{array}$ \\
\hline
\end{tabular}


Appendix A. Summary of generator interviews.

Page 6 of 8

\begin{tabular}{|c|c|c|c|}
\hline $\begin{array}{l}\text { Researcher } \\
\text { Number }\end{array}$ & Process Descriptions & Previous Generation & $\begin{array}{c}\text { Current Generation/ Waste } \\
\text { Minimization }\end{array}$ \\
\hline \multirow[t]{3}{*}{12.} & $\begin{array}{l}\text { DNA sequencing with } \\
\text { autoradiography }\end{array}$ & $\begin{array}{l}\text { Uses }{ }^{32} \mathrm{P} \text { and }{ }^{35} \mathrm{~S} \text {. Does } \\
\text { not fix or wash gel, } \\
\text { therefore no LLMW } \\
\text { generation from DNA } \\
\text { sequencing. }\end{array}$ & Does not fix the DNA gel. \\
\hline & $\begin{array}{l}\text { Nonradioactive staining } \\
\text { following autoradiography }\end{array}$ & $\begin{array}{l}\text { Use some nonradioactive } \\
\text { DNA staining with } \\
\text { ethidium bromide (a } \\
\text { mutagen) or Coomassie } \\
\text { Blue after autoradiography. } \\
\text { Staining requires } 10 \% \text { to } \\
50 \% \text { methanol and } 10 \% \\
\text { acetic acid for fixing and } \\
\text { washing, generating }\end{array}$ & $\begin{array}{l}\text { No specific waste } \\
\text { minimization techniques. }\end{array}$ \\
\hline & Protein separations & $\begin{array}{l}\text { LLMW. } \\
\text { Uses } 20 \% \text { isopropanol } \\
\text { fixer/washer to get rid of } \\
\text { the SDS, but it does not } \\
\text { denature the protein. }\end{array}$ & $\begin{array}{l}\text { Effective product } \\
\text { substitution, as } \\
\text { isopropanol is not a } \\
\text { LLMW. }\end{array}$ \\
\hline \multirow[t]{2}{*}{13.} & TCA protein precipitations & $\begin{array}{l}\text { Waste consists of } \sim / \mu \mathrm{Ci} / \mathrm{ml} \\
{ }^{3} \mathrm{H} \text { in } 5 \% \mathrm{TCA} \\
\text { Generation rate of } 10 \\
\text { gallons per year. }\end{array}$ & $\begin{array}{l}\text { Discontinued adding } \\
\text { hydrochloric acid to mixed } \\
\text { waste container. This } \\
\text { waste can be neutralized in } \\
\text { laboratory and does not } \\
\text { require misiagement as } \\
\text { LLMW. }\end{array}$ \\
\hline & $\begin{array}{l}\text { TCA protein precipitation } \\
\text { on filter paper }\end{array}$ & $\begin{array}{l}\text { Waste consists of } \\
\sim 0.1 \mu \mathrm{Ci} / \mathrm{ml}{ }^{14} \mathrm{C} \text { in } 5 \% \\
\mathrm{TCA}\end{array}$ & \\
\hline 14. & $\begin{array}{l}\text { HPLC and FPLC with } \\
\text { LSC }\end{array}$ & $\begin{array}{l}\text { Uses }{ }^{14} \mathrm{C} \text { labeled enzymes. } \\
\text { LLMW constituents } \\
\text { include isobutanol and } \\
\text { hydrochloric acid along } \\
\text { with buffers and LSC } \\
\text { fluors. }\end{array}$ & $\begin{array}{l}\text { Generates approximately } \\
\text { one liter of LLMW per } \\
\text { month. Waste separates } \\
\text { into two phases; one } \\
\text { organic and the other } \\
\text { acidic. }\end{array}$ \\
\hline
\end{tabular}


Appendix A. Summary of generator interviews.

Page 7 of 8

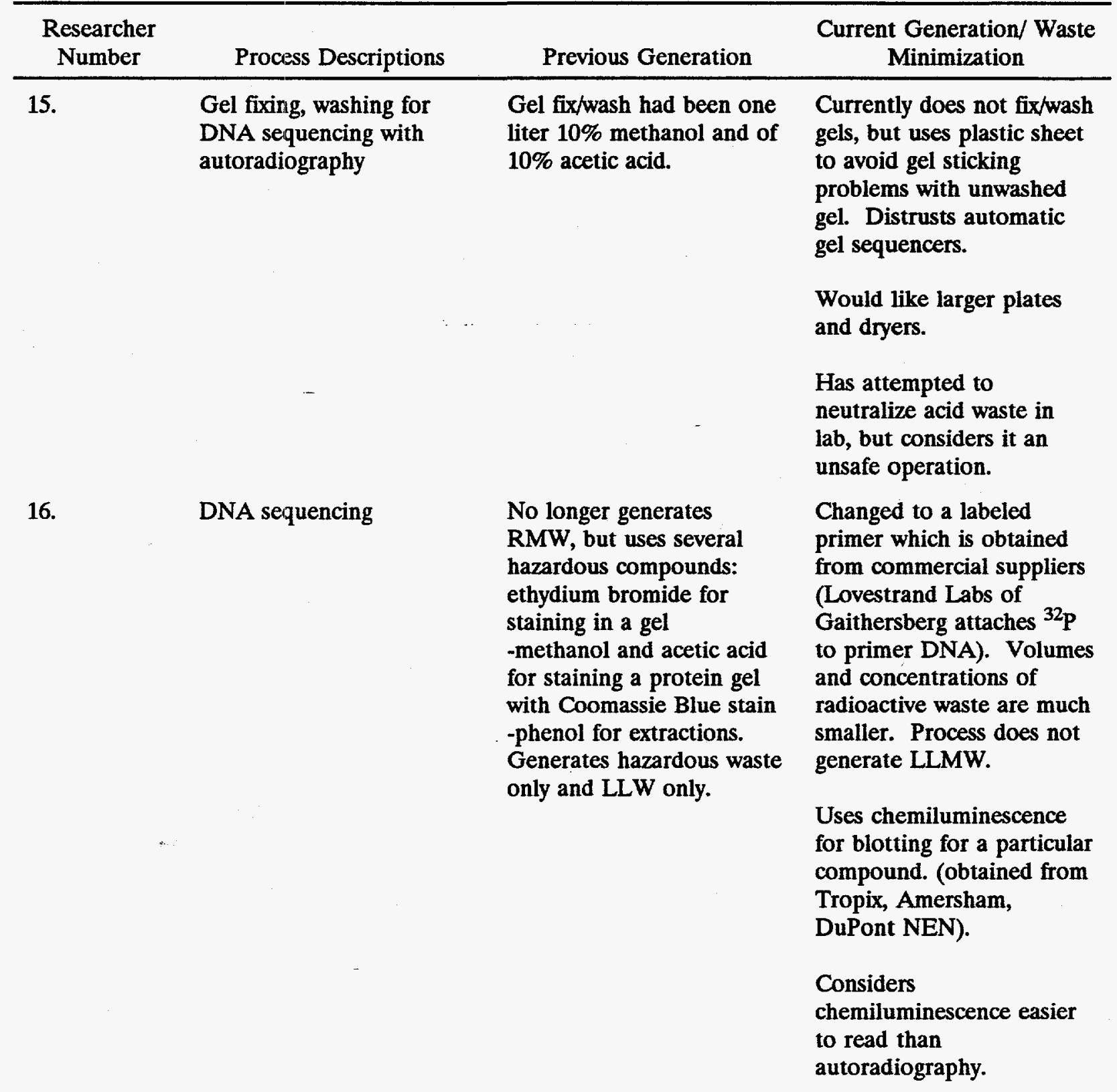


Appendix A. Summary of generator interviews.

Page 8 of 8

\begin{tabular}{|c|c|c|c|}
\hline $\begin{array}{l}\text { Researcher } \\
\text { Number }\end{array}$ & Process Descriptions & Previous Generation & $\begin{array}{c}\text { Current Generation/ Waste } \\
\text { Minimization }\end{array}$ \\
\hline 17. & Cell culture & $\begin{array}{l}\text { Multiple cell culture tubes, } \\
\text { each generating } \\
\text { approximately } 25 \mathrm{ml} \text { of } \\
\text { chloroform/aqueous wastes. } \\
\text { LLMW generation is } \\
\text { approximately } 5 \text { gallons } \\
\text { with } 7 \% \text { chloroform every } \\
\text { month. }\end{array}$ & $\begin{array}{l}\text { No significant effort for } \\
\text { waste minimization is } \\
\text { currently employed. } \\
\text { Potential exists to separate } \\
\text { chloroform from aqueous } \\
\text { waste, as waste jug has } \\
\text { 2-phases. } \\
\text { Potential for development } \\
\text { of RIA procedure for } \\
\text { melanin. Impediment to } \\
\text { development and use is the } \\
6 \text { months to } 1 \text { year } \\
\text { required for validation of } \\
\text { alternate procedure, } \\
\text { without guarantee of } \\
\text { success. }\end{array}$ \\
\hline \multirow[t]{2}{*}{18.} & $\begin{array}{l}\text { Gel washing/fixing, largest } \\
\text { volume of waste from } \\
\text { HPLC }\end{array}$ & $\begin{array}{l}\text { Had generated large } \\
\text { volumes of HPLC wastes. }\end{array}$ & $\begin{array}{l}\text { Currently generates little } \\
\text { RMW, as research now } \\
\text { focuses on } 3 \text { metabolites } \\
\text { (down from 15, } \\
\text { previously). }\end{array}$ \\
\hline & & $\begin{array}{l}\text { Disposal and management } \\
\text { of HPLC waste was a } \\
\text { nuisance. Occasional spills } \\
\text { resulted if waste jug was } \\
\text { not changed frequently. } \\
\text { Laboratory now gathers as } \\
\text { much data using } \\
\text { radioimmunoassay } \\
\text { technique and does not } \\
\text { generate LLMW. }\end{array}$ & $\begin{array}{l}\text { Prefers enzyme } \\
\text { immunoassay over } \\
\text { radiographic and } \\
\text { spectrophotometric } \\
\text { methods. (Suppliers } \\
\text { include Amersham, } \\
\text { DuPont NEN, Advanced } \\
\text { Magnetics, Serogen). }\end{array}$ \\
\hline 19. & Cell culture & $\begin{array}{l}\text { Uses }{ }^{3} \mathrm{H} \text {-thymidine in } \\
\text { reverse transcriptase (RT) } \\
\text { assay. Uses } 10 \% \text { TCA to } \\
\text { stop reaction and } 100 \% \\
\text { methanol rinse. Waste is } \\
\text { estimated at } 60 \% \text { TCA and } \\
40 \% \text { methanol. TCA } \\
\text { attacks cell harvester. } \\
\text { Researchers must use } 12 \\
\text { cell harvester, instead of } 96 \\
\text { cell harvester. 10-15 } \\
\text { gallons of waste from RT. }\end{array}$ & $\begin{array}{l}\text { Use more modern } 96 \text { cell } \\
\text { harvester to reduce volume } \\
\text { of waste. }\end{array}$ \\
\hline 20. & $\begin{array}{l}\text { Chloroform/phenol } \\
\text { extractions; Western blots }\end{array}$ & $\begin{array}{l}5 \text { gallons/month from } \\
\text { chloroform/phenol } \\
\text { extractions. Waste also } \\
\text { included } 10-20 \% \text { methanol } \\
\text { and } 10 \% \text { acetic acid. }\end{array}$ & $\begin{array}{l}\text { Now uses gel that does not } \\
\text { require fixing. Uses } \\
\text { isotopically labeled DNA- } \\
\text { probes that do not } \\
\text { generate LLMW. }\end{array}$ \\
\hline
\end{tabular}

